\title{
Detection of Plasma Biomarkers Using Immunomagnetic Reduction: A Promising Method for the Early Diagnosis of Alzheimer's Disease
}

\author{
Shieh-Yueh Yang • Ming-Jang Chiu • Ta-Fu Chen · Herng-Er Horng
}

Received: February 20, 2017

(C) The Author(s) 2017. This article is an open access publication

\section{ABSTRACT}

Alzheimer's disease (AD) is the most common form of dementia. The development of assay technologies able to diagnose early-stage $\mathrm{AD}$ is

Enhanced content To view enhanced content for this article go to http://www.medengine.com/Redeem/ CAD8F06039796B6E.

Shieh-YuehYang ( $₫)$

MagQu Co., Ltd., New Taipei City 231, Taiwan

e-mail: syyang@magqu.com

Ming-JangChiu · Ta-FuChen

Department of Neurology, National Taiwan

University Hospital, College of Medicine, National

Taiwan University, Taipei 110, Taiwan

Ming-JangChiu

Graduate Institute of Brain and Mind Sciences, College of Medicine, National Taiwan University, Taipei 110, Taiwan

Ming-JangChiu

Department of Psychology, National Taiwan

University, Taipei 110, Taiwan

Ming-JangChiu

Graduate Institute of Biomedical Engineering and Bioinformatics, National Taiwan University, Taipei 116, Taiwan

\section{Herng-ErHorng}

Institute of Electro-Optical Science and Technology, National Taiwan Normal University, Taipei 116, Taiwan important. Blood tests to detect biomarkers, such as amyloid and total Tau protein, are among the most promising diagnostic methods due to their low cost, low risk, and ease of operation. However, such biomarkers in blood occur at extremely low levels and are difficult to detect precisely. In the early 2000s, a highly sensitive assay technology, immunomagnetic reduction (IMR), was developed. IMR involves the use of antibody-functionalized magnetic nanoparticles dispersed in aqueous solution. The concentrations of detected molecules are converted to reductions in the ac magnetic susceptibility of this reagent due to the association between the magnetic nanoparticles and molecules. To achieve ultra-high sensitivity, a high-Tc superconducting-quantum-interference-device (SQUID) ac magnetosusceptometer was designed and applied to detect the tiny reduction in the ac magnetic susceptibility of the reagent. Currently, a 36-channeled high-Tc SQUID-based ac magnetosusceptometer is available. Using the reagent and this analyzer, extremely low concentrations of amyloid and total Tau protein in human plasma could be detected. Further, the feasibility of identifying subjects in early-stage $\mathrm{AD}$ via assaying plasma amyloid and total Tau protein is demonstrated. The results show a diagnostic accuracy for prodromal $\mathrm{AD}$ higher than $80 \%$ and reveal the possibility of screening for early-stage AD using SQUID-based IMR. 
Keywords: Alzheimer's

disease; Immunomagnetic reduction; Magnetic nanoparticles; Plasma biomarkers; SQUID

\section{INTRODUCTION}

Neurodegenerative diseases, referred as to dementia, have become more prevalent in aging societies. Alzheimer's disease (AD) is the most common form of dementia [1]. Currently, more than 45 million people are diagnosed as probable $\mathrm{AD}$, and an additional 130 million people might have mild cognitive impairment (MCI) due to AD [2-4]. The cost of AD-related healthcare is considerable $[5,6]$. In the near future, with the availability of disease-modifying drugs, it will be necessary to have conveniently available, accurate diagnostic procedures. Many countries, such as the US, UK, China, Japan, and Germany, have been allocating resources to help researchers develop early-stage diagnostics or therapeutic drugs for AD-related diseases [7-9].

According to pathological analysis, AD subjects show amyloid $\beta(A \beta)$ plaques in the brain cortex [10-13]. A $\beta$ s are peptides of 36-43 amino acids that result from cleavage of the amyloid precursor protein (APP) by the $\beta$ and $\gamma$ secretases. A $\beta$ molecules can aggregate to form flexible, soluble oligomers in the brain and can be naturally metabolized. However, certain misfolded oligomers induce the formation of $A \beta$ plaques in the brain [13] and cause damage to neurons, particularly those surrounding the hippocampus, which functions in short-term memory [14, 15]. Thus, subjects show disorders in memory and even cognitive decline. Another possible mechanism for $\mathrm{AD}$ is the hyperphosphorylation of Tau proteins, which are abundant in brain neurons and stabilize the microtubules of neurons [17-20]. The hyperphosphorylation of Tau proteins causes the death of neurons, resulting in the expression of Tau protein from neurons. Meanwhile, due to the death of neurons, neurofibrillary tangles can be observed in the biopsy and the atrophy of the hippocampus occurs [21, 22]. Therefore, three main clinical features occur with $\mathrm{AD}$. The first is $A \beta$ plaques and neurofibrillary tangles in the brains of $\mathrm{AD}$ subjects. The second is atrophy of the hippocampus. The third is memory or cognitive disorders. In clinics, amyloid positron emission tomography (amyloid-PET) is used for imaging $A \beta$ plaques [23-25]. Tau-PET for imaging neurofibrillary tangles in the brain is under development and can only be used experimentally [26, 27]. Magnetic resonance imaging (MRI) is used for observing atrophy of the hippocampus [28-30]. Neuropsychological tests are applied to evaluate memory or cognitive function [31-36]. However, there are several disadvantages with the currently used diagnostic procedures. For example, the cost for an amyloid-PET is $\$ 4000$ (USD). Moreover, the contrast medium of amyloid-PET or Tau-PET is radiological and may have negative effects on subjects. Although MRI can be used in the early-stage diagnosis of $\mathrm{AD}$, it cannot be applied to some subjects, such as those with heart stent or pacemaker. Approximately $3 \mathrm{~h}$ are required to complete a detailed subject examination, including neuropsychological tests performed by a neurophysiologist. Hence, neither neuro-imaging nor neuropsychological tests can be applied for large-scale, early-stage screening for $\mathrm{AD}$.

Both $A \beta$ plaques and neurofibrillary tangles are the neuropathological hallmarks of AD [10-20]. Even in the early stage of $\mathrm{AD}$, the concentrations of $A \beta s$ and Tau protein in the cerebrospinal fluid (CSF) become abnormal [37-40]. Most studies indicated that the concentration of Tau protein in the CSF increases, whereas the concentrations of $\mathrm{A} \beta_{1-42}$ in the CSF decreases in $\mathrm{AD}$ subjects [41-45]. The diagnostic accuracy of $\mathrm{AD}$ using the above-mentioned CSF biomarkers is $80 \%-95 \%$ $[46,47]$. Thus, the assay of CSF biomarkers could be used for the early-stage diagnosis of AD. However, it takes a lumbar puncture to obtain CSF. Although the lumbar puncture carriers low risk, it may bring discomfort to subjects. As of yet, there is no safe, comfortable, low-cost, large-scale, early-stage diagnostic method for AD. Such an urgent demand drives a tremendous number of researchers to develop new technologies for clinical uses.

Blood is a very common sample in clinical practice. In contrast to lumbar puncture, venipuncture is rather safe, less uncomfortable, 
and inexpensive. The difficulty in assaying $\mathrm{AD}$ biomarkers in human blood is due to the ultra-low concentrations of biomarkers. The concentrations of $\mathrm{AD}$ biomarkers in CSF are sub-ng/ml or several $\mathrm{ng} / \mathrm{mL}$ [41-47], while blood biomarkers are at much lower levels of $\mathrm{pg} / \mathrm{mL}[48,49]$. This means that the required limit of detection (LoD) for assaying $A \beta$ or Tau protein in human blood should be several pg/ mL. Currently used assay technologies in clinics, such as enzyme-linked immunosorbent assay, turbidimetry, and nephelometry [50-52], demonstrate LoD values in the hundreds of $\mathrm{pg} /$ $\mathrm{mL}$, which is much higher than the required LoD for assaying blood $A \beta$ and Tau protein. Thus, an ultra-high-sensitivity technology is needed to assay ultra-low-concentration $A \beta$ and Tau protein in human blood for the early-stage diagnosis of AD.

Herein, the authors describe the development of an ultra-high-sensitivity detection technology for protein: immunomagnetic reduction (IMR) $[53,54]$. In IMR, the reagent is a phosphate-buffered saline (PBS) solution having homogeneously dispersed magnetic nanoparticles, which are coated with hydrophilic surfactants (e.g., dextran) and bio-probes (e.g., antibodies) [55]. Under multiple external alternative-current (ac) magnetic fields, magnetic nanoparticles oscillate via magnetic interaction. Thus, the reagent under multiple external ac magnetic fields shows a magnetic property, termed mixed-frequency ac magnetic susceptibility, $\chi_{\mathrm{ac}}$, as illustrated in Fig. 1a. Via the bio-probes on the outermost shell, magnetic nanoparticles associate with target molecules to magnetically label the molecules. Because of this association, magnetic nanoparticles

(a) $\chi_{\mathrm{ac}, \mathrm{o}}$

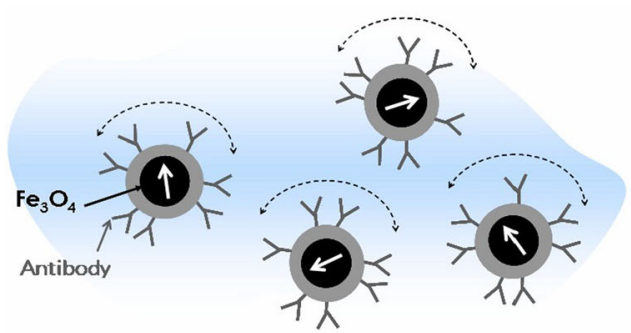

become larger, as schematically shown in Fig. $1 \mathrm{~b}$. The $\chi_{\mathrm{ac}}$ response of these larger magnetic nanoparticles to external multiple ac magnetic fields is much less than that of the original individual magnetic nanoparticles. Thus, the $\chi_{\mathrm{ac}}$ of the reagent is reduced due to the association between magnetic nanoparticles and target molecules. In principle, when greater amounts of target molecules are mixed with a reagent, more magnetic nanoparticles become larger. A larger reduction in $\chi_{\mathrm{ac}}$ could be expected for reagents. The reduction in $\chi_{\mathrm{ac}}$ is referred to as the IMR signal, IMR (\%), and is quantified via

$$
\operatorname{IMR}(\%)=\frac{\chi_{\mathrm{ac}, \mathrm{o}}-\chi_{\mathrm{ac}, \phi}}{\chi_{\mathrm{ac}, \mathrm{o}}} \times 100 \%,
$$

where $\chi_{\mathrm{ac}, \mathrm{o}}$ and $\chi_{\mathrm{ac}, \phi}$ are the ac magnetic susceptibilities of the reagent before and after the association between magnetic nanoparticles and target molecules. In the case of ultra-low concentrations with target molecules, tiny portions of magnetic nanoparticles associate with target molecules. The reduction in the ac magnetic susceptibility of the reagent would be very low. To achieve high-sensitivity detections, a magnetic sensor able to detect the tiny change in the ac magnetic susceptibility of the reagent is required. The high-Tc superconducting-quantum interference-device (SQUID) magnetometer is a promising sensor candidate for IMR measurement. The high-Tc SQUID-based ac magnetosusceptometer for IMR measurement has been developed since 2008 [54]. Currently, the 36-channeled SQUID-based IMR analyzer is available in specific markets. With the aid of antibody-functionalized magnetic

(b) $\chi_{\mathrm{ac}, \phi}\left(<\chi_{\mathrm{ac}, \mathrm{o}}\right)$

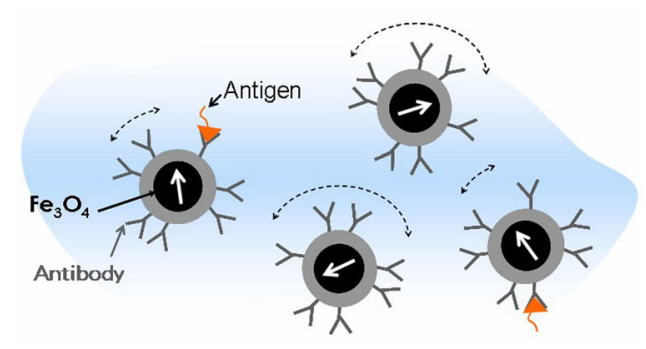

Fig. 1 Illustration of the mechanism of immunomagnetic reduction (IMR) 
nanoparticles and a SQUID-based ac magnetosusceptometer, the LoDs for assaying proteins such as vascular endothelial growth factor (VEGF) and $\alpha$-synuclein, and viruses like H5N1 are as low as $\mathrm{pg} / \mathrm{mL}$ [56-58]. These results reveal the possibility of assaying $\mathrm{A} \beta$ and Tau protein, which might be at the levels of tens of $\mathrm{pg} / \mathrm{ml}$, in human blood.

IMR is not the only one technology reported for the ultra-sensitivity assay. Other technologies such as single molecule assay (SIMOA) or single molecule counting (SMC) have been developed [59-62]. As compared to SIMOA or SMC, IMR shows the technical advantages. SIMOA and SMC use magnetic beads for the purifications of target molecules (or to concentrate target molecules). This process usually causes loss of target molecules. IMR is a direct measurement of target molecules. Hence, the levels of molecules such as plasma tau protein detected with SIOMA and SMC are lower than that of IMR. Furthermore, SIMOA and SMC are ELISA-based. Sandwich technology is used in SIMOA and SMC. Such technology does not perform well for assaying small molecules. As to IMR, only primary antibody is used. IMR can be widely applied to assay molecules of any sizes.

In this article, the preparation of reagents containing antibody-functionalized magnetic nanoparticles for assaying $A \beta$ and total Tau protein is described. In addition, the design of the high-Tc SQUID-based IMR analyzer is illustrated. Moreover, the characterizations of detecting $A \beta$ and total Tau protein using the reagents and the analyzer are explored. One hundred and twenty-three human plasma samples are analyzed with IMR measurement for $A \beta$ and total Tau protein to investigate the feasibility of discriminating healthy control volunteers from early-stage-AD subjects.

\section{METHODS USED IN ORIGINAL STUDIES}

\section{Synthesis of Antibody-Functionalized Magnetic Nanoparticles}

The magnetic nanoparticles used are dextran-coated $\mathrm{Fe}_{3} \mathrm{O}_{4}$ particles (MF-DEX-0060,
MagQu Co., Ltd.), as shown in Fig. 1. These nanoparticles are dispersed in phosphate-buffered saline (PBS) solution. The mean hydrodynamic diameter of the particles is $50-60 \mathrm{~nm}$ measured with laser dynamic scattering (Nanotrac 150, Microtrac). The diameter of core $\mathrm{Fe}_{3} \mathrm{O}_{4}$ is approximately $25-30 \mathrm{~nm}$ according to the $\theta-2 \theta$ X-ray powder diffraction pattern (D-500, Simens) for the (311) peak [55]. The dextran serves as a surfactant to achieve dispersion of the magnetic nanoparticles in the PBS and also acts as a linker between the $\mathrm{Fe}_{3} \mathrm{O}_{4}$ particles and antibodies. For antibodies to bind to dextran on the outermost shell of the magnetic nanoparticles, $\mathrm{NaIO}_{4}$ solution is added into the magnetic solution to oxidize dextran to create aldehyde groups (-CHO) [63]. Then, dextran can react with the antibodies via the linking of $-\mathrm{CH}=\mathrm{N}-$. Thus, the antibody is bound covalently to dextran. Through magnetic separation, unbound antibodies are separated from the solution. In this work, two types of antibodies, targeting $A \beta_{1-42}$ and Tau protein, are separately immobilized onto magnetic nanoparticles. For the $\mathrm{A} \beta_{1-42}$ reagent (MF-AB2-0060, MagQu Co., Ltd.), the antibody is monoclonal (A8354, Sigma). The antibody for Tau reagent (MF-TAU-0060, MagQu Co., Ltd.) is also monoclonal (T9450, Sigma) and is against the $\mathrm{C}$ terminal region of Tau protein. Thus, total Tau protein is measured. Hereafter, the total Tau protein is referred to as Tau protein in this study. The concentration of reagent is $8 \mathrm{mg} \mathrm{Fe} / \mathrm{ml}$, and both reagents demonstrate superparamagnetism. The reagents were stored at $2-8{ }^{\circ} \mathrm{C}$ and showed stability at 130 days.

\section{Mechanism of Immunomagnetic Reduction}

The detailed mechanism of immunomagnetic reduction (IMR) using the antibody-functionalized magnetic nanoparticles is described here. The frequency-dependent ac magnetic susceptibility $\chi_{\mathrm{ac}}$ of the reagent under an external magnetic field is expressed as

$$
\chi_{\mathrm{ac}}=\chi_{\mathrm{o}}\left[\frac{1}{1+\left(2 \pi f \tau_{\mathrm{eff}}\right)^{2}}+\frac{\left(2 \pi f \tau_{\mathrm{eff}}\right)^{2}}{1+\left(2 \pi f \tau_{\mathrm{eff}}\right)^{2}}\right]^{1 / 2} \mathrm{e}^{i \theta}
$$


where $\chi_{\mathrm{o}}$ is the dc magnetic susceptibility, $f$ is the frequency of the external magnetic field, and $\tau_{\text {eff }}$ is the effective time constant of magnetic relaxation of magnetic nanoparticles in reagent. $\tau_{\text {eff }}$ can be written as

$$
1 / \tau_{\text {eff }}=1 / \tau_{B}+1 / \tau_{N},
$$

where $\tau_{B}$ and $\tau_{N}$ are the time constants of Brownian relaxation and Néel relaxation. $\tau_{B}$ and $\tau_{N}$ are expressed as $[64,65]$

$$
\begin{gathered}
\tau_{B}=\frac{3 \eta V_{\mathrm{H}}}{k_{B} T}, \\
\tau_{N}=\exp \left(\frac{\kappa V_{\mathrm{M}}}{k_{B} T}\right),
\end{gathered}
$$

where $\eta$ is the viscosity of the water, $V_{\mathrm{H}}$ is the hydrodynamic volume of a nanoparticle, $k_{B}$ is the Boltzmann constant, $T$ is the temperature in Kelvin, $\kappa$ is the anisotropy constant of nanoparticles, and $V_{\mathrm{M}}$ denotes the volume of the magnetic core of a nanoparticle. When the viscosity of water $\left(=10^{-3} \mathrm{~Pa}-\mathrm{s}\right)$, the hydrodynamic diameter of the magnetic nanoparticles $(\sim 55 \mathrm{~nm})$, the measurement temperature $(\sim 293 \mathrm{~K})$, the anisotropy constant of magnetic nanoparticles $\left(\sim 30 \mathrm{~kJ} \mathrm{~m}^{-3}\right)$, and the core diameter of magnetic nanoparticles $(\sim 30 \mathrm{~nm})$ are known, the $\tau_{B}$ is estimated to be microseconds and $\tau_{N}$ is approximately $1061 \mathrm{~s}$. Since $\tau_{N}$ is much larger than $\tau_{B}$, the second term on the right-hand side of Eq. (3) can be neglected. In the current case, $\tau_{\text {eff }}$ can be regarded as $\tau_{B}$. Thus, the normalized amplitude of ac magnetic susceptibility, $\left|\chi_{\mathrm{ac}}\right| / \chi_{\mathrm{o}}$, in Eq. (2) as a function of frequency of an external magnetic field can be numerically analyzed with the known values of $\eta, V_{\mathrm{H}}, k_{B}$ and $T$ in Eq. (4a). Figure 2 plots the relationship between the normalized amplitude of ac magnetic susceptibility and the frequency of the applied ac magnetic field, i.e., the $\left|\chi_{\mathrm{ac}}\right| /$ $\chi_{\text {o-f }}$ curve. For a given mean hydrodynamic diameter of particles, say $50.8 \mathrm{~nm}$, the $\left|\chi_{\mathrm{ac}}\right| / \chi_{\mathrm{o}}$ continuously decreases with increasing frequency. On the other hand, as the mean hydrodynamic diameter of the particles increases, the $\left|\chi_{\mathrm{ac}}\right| / \chi_{\mathrm{o}-\mathrm{f}}$ curve moves downward. These results contribute to the reduction in the ac

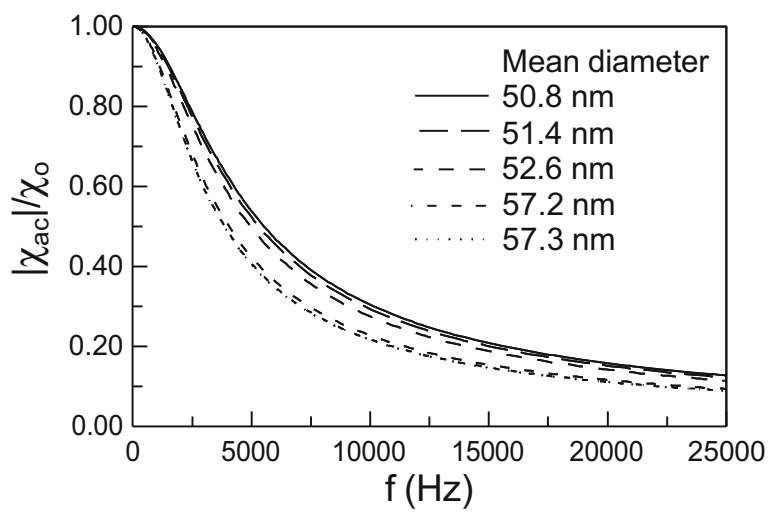

Fig. 2 Frequency-dependent normalized amplitude of ac magnetic susceptibility of reagents with various sizes of nanoparticles [52]. The frequency is that of the applied ac magnetic field

magnetic susceptibility of the reagent as antibody-functionalized magnetic nanoparticles associate with target molecules.

Equation (2) gives the ac magnetic susceptibility of the reagent under only one applied ac magnetic field. In IMR, two magnetic fields, $H_{1}$ and $H_{2}$, are applied to the reagent. These two applied magnetic fields have different frequencies, $f_{1}$ and $f_{2}$. The amplitudes of the two applied magnetic fields are weak, e.g., $<1$ Gauss. Thus, the effective ac magnetic susceptibility of the reagent can be expressed as [53]

$$
\begin{aligned}
\chi_{\mathrm{ac}, \mathrm{eff}}= & 0.32\left(\chi_{\mathrm{ac}, \mathrm{H}_{1}}+\chi_{\mathrm{ac}, \mathrm{H}_{2}}\right) / k_{B} T-0.12\left(\chi_{\mathrm{ac}, \mathrm{H}_{1}}\right. \\
& \left.+\chi_{\mathrm{ac}, \mathrm{H}_{2}}\right)^{3} /\left(k_{B} T\right)^{3}+\ldots
\end{aligned}
$$

where $\chi_{\mathrm{ac}, \mathrm{H} 1}$ is attributed to $H_{1}$ with frequency $f_{1}, \chi_{\mathrm{ac}, \mathrm{H} 2}$ results from $H_{2}$ with frequency $f_{2}, k_{B}$ is the Boltzmann constant, and $T$ is the absolute temperature.

The frequencies shown in the first term on the right-hand side are $f_{1}$ and $f_{2}$, whereas the second term exhibits frequencies of $f_{1}, f_{2}, 3 f_{1}$, $3 f_{2}, f_{2}-2 f_{1}, f_{2}+2 f_{1}, f_{1}-2 f_{2}, f_{1}+2 f_{2}$. One can select any linear combination of $f_{1}$ and $f_{2}$. In IMR, the frequency of $f_{1}+2 f_{2}$ is of interest. Thus, the amplitude (denoted as $\chi_{\text {ac,amp}}$ ) for $\chi_{\text {ac,eff }}$ at $f_{1}+2 f_{2}$ is proportional to the product of $\chi_{\mathrm{ac}, \mathrm{H} 1}$ at $f_{1}$ and $\left(\chi_{\mathrm{ac}, \mathrm{H} 2}\right)^{2}$ at $f_{2}$;

$$
\chi_{\mathrm{ac}, \mathrm{amp}}=\chi_{\mathrm{ac}, \mathrm{H}_{1}} \cdot\left(\chi_{\mathrm{ac}, \mathrm{H}_{2}}\right)^{2}
$$


Once the antibody-functionalized magnetic nanoparticles associate with the target molecules, the hydrodynamic volume of the associated nanoparticles increases. Meanwhile, both $\chi_{\mathrm{ac}, \mathrm{H} 1}$ and $\chi_{\mathrm{ac}, \mathrm{H} 2}$ show a given frequency decrease. Thus, this results in a reduction in the ac magnetic susceptibility of the reagent [66].

\section{Multi-Channeled SQUID-Based ac Magnetosusceptometer}

The signal-channeled SQUID-based ac magnetometer was developed in 2008 [54]. The SQUID-based ac magnetosusceptometer consists of three parts: sample magnetization, flux coupling, and superconducting sensing, as shown in Fig. 3. The sample-magnetization component is a set of coils, including two excitation coils (referred to as excitation coil 1 and excitation coil 2, respectively) and one pick-up coil. The inductances and resistance of the three coils are listed in Table 1 . The three coils are assembled coaxially, with the pick-up coil being innermost. Excitation coils are driven with an ac signal generator, generating two independent ac voltages at two different frequencies, $f_{1}$ and $f_{2}$, to excitation coils 1 and 2 . The pick-up coil is an axial gradiometer. The ac magnetic signal from the sample is detected by the pick-up coil and is transmitted to the flux coupling component.

The flux-coupling component is a pair of twisted wires, as illustrated in Fig. 4. One end of the wires is connected to the pick-up coil. The other end of the wires is terminated with a coil. Once the output ac voltage of the pick-up coil is

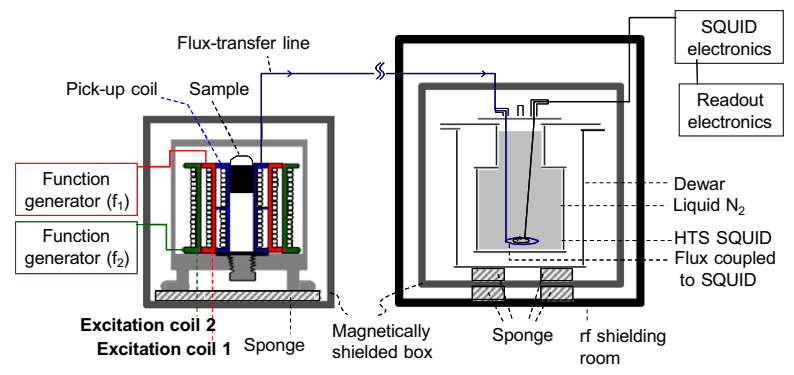

Fig. 3 Configuration of the single-channel high-Tc SQUID ac magnetosusceptometer for IMR measurement [44]
Table 1 Inductance and resistance coils of the high-Tc SQUID-based ac magnetosusceptometer

\begin{tabular}{lcc}
\hline & Inductance $(\mathbf{m H})$ & Resistance $(\mathbf{\Omega})$ \\
\hline Excitation coil 1 & $4.21-4.26$ & $18.71-18.80$ \\
Excitation coil 2 & $2.72-2.77$ & $14.94-15.02$ \\
Pick-up coil & $0.190-0.198$ & $2.56-2.62$ \\
\hline
\end{tabular}

activated, an ac electric current $I$ is induced along the wires, and an ac magnetic field $B$ is generated at the coil terminal. The ac magnetic field $B$ at the coil terminal is detected with the high-Tc SQUID magnetometer, which is the superconducting-sensing component. The mutual inductance between the coil terminal and the SQUID magnetometer is $1.6 \mu \mathrm{H}$. By utilizing the flux-coupling coil, the ac magnetic flux originally generated at the sample component is efficiently transferred to the sensor component of the SQUID-based ac magnetosusceptometer. With this setup, the SQUID magnetometer is not seriously disturbed by the two excitation fields, because the excitation fields are distant from the SQUID magnetometer. Thus, the system is very stable and is suitable for long-term operation. Note that the flux-coupling coil is enveloped with electromagnetically shielded shells.

The SQUID magnetometer and the coil terminal are immersed in liquid nitrogen. The dewar is placed inside an electromagnetically shielded box, showing $100 \mathrm{~dB}$ for the shielding factor at the operating frequency $(\sim 20 \mathrm{kHz})$. The SQUID magnetometer is controlled electronically, and the output signals are sent to a personal computer (PC).

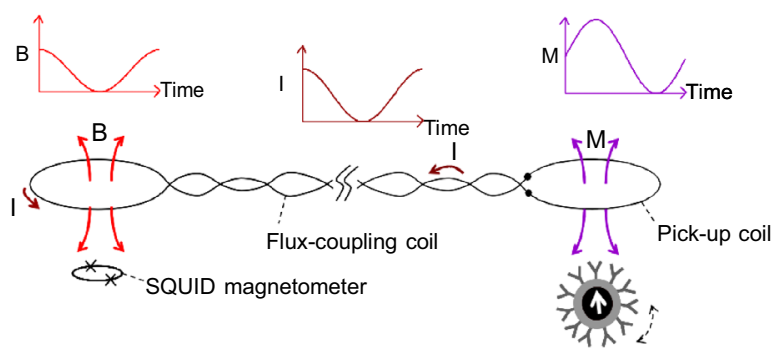

Fig. 4 Illustration of the working principle of the flux-coupling module used with the high-Tc SQUID ac magnetosusceptometer 
With the need for a high-throughput assay, the channel numbers of the SQUID-based ac magnetosusceptometer were increased to 4 in $2010[67,68]$, to 8 in 2014 , and finally to 36 in 2016. An image of the 36-channel SQUID-based ac magnetosusceptometer is shown in Fig. 5 . With increases in the channel numbers, more electrical technologies are integrated into the magnetosusceptometer. For example, to prevent electromagnetic crosstalk among coil sets, two neighboring coil sets are separated by $15 \mathrm{~cm}$ or each coil set is surrounded with an electromagnetic absorber. The coil sets are activated in sequence. Only one coil set is activated at one instance. To manipulate the activation of each coil set, low-noise electric switches are cascaded between the ac signal generator and excitation coils and between the pick-up coil and the flux-coupling coil component. A 105-channeled SQUID-based ac magnetosusceptometer is under development.

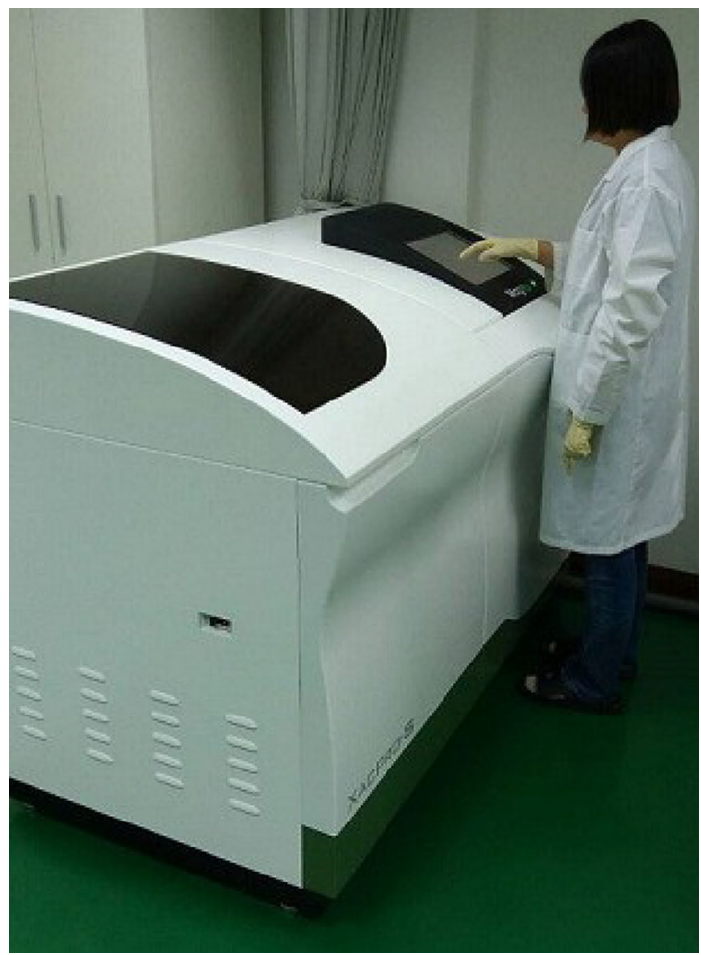

Fig. 5 Photo of the 36-channel high-Tc SQUID ac magnetosusceptometer for IMR measurement

\section{Recruitment of Subjects}

This article is based on previously conducted studies [22, 24, 28] and does not involve the performance of any new studies of human or animal subjects. In the previous studies, all subjects were recruited at National Taiwan University Hospital. AD subjects and healthy control volunteers were enrolled from a memory clinic and a mild-cognitive-impairment (MCI) project, respectively. The demographic information of the subjects is listed in Table 2. All subjects had completed primary-school education, and none displayed depressive symptoms, i.e., Geriatric Depression Scale score $>8$. Subjects with major systemic diseases possibly affecting cognitive function, such as cardiopulmonary failure, hepatic or renal failure, poorly controlled diabetes $(\mathrm{HbA} 1 \mathrm{C}>8.5)$, head injury, stroke or other neurodegenerative disease, were excluded. All subjects have been diagnosed by experienced physicians at National Taiwan University Hospital.

Several clinical diagnostic tests were performed for the subjects to classify them as healthy controls, MCI due to $\mathrm{AD}$, or $\mathrm{AD}$. The clinical workup included medical history, physical and neurological examinations, laboratory tests, and neuroimaging studies. The neurological examinations included the Mini-Mental State Examination (MMSE) and Clinical Dementia Rating (CDR), the Activities of Daily Living (ADL) scale, the Instrumental ADL scale, and the Wechsler Memory Scale-III (WMS-III). Subjects with dementia meet the diagnostic guidelines for probable AD dementia proposed by the National Institute on Aging-Alzheimer's Association (NIA-AA) workgroups in 2011. The diagnosis of MCI due to AD also follows the recommendations of the NIA-AA. For the diagnosis of MCI due to AD, a formal cognitive test is used, with a cutoff value at or below the fourth percentile (lower than 1.5 times the standard deviation) of the scale score for the age- and education-matched control. Additionally, all subjects with MCI due to AD demonstrated hippocampal atrophy as observed by magnetic resonance imaging [22].

As shown in Table 2, MMSE scores varied among groups. MMSE was $28.6 \pm 1.1$ for 
Table 2 Demographic information of enrolled subjects

\begin{tabular}{llll}
\hline Group & Healthy control & MCI due to AD & Early-stage AD \\
\hline Numbers & 68 & 24 & 31 \\
Age $($ years $)$ & $62.7 \pm 9.7$ & $71.0 \pm 10.3$ & $72.1 \pm 10.7$ \\
CDR & 0 & 0.5 & $0.5-1$ \\
MMSE & $28.6 \pm 1.1$ & $24.6 \pm 2.2^{*}$ & $22.2 \pm 2.9^{*},^{\dagger}$ \\
$\phi_{\text {A } 1-42}(\mathrm{pg} / \mathrm{mL})$ & $15.82 \pm 0.73$ & $17.52 \pm 1.22$ & $18.61 \pm 1.55$ \\
$\phi_{\text {Tau }}(\mathrm{pg} / \mathrm{mL})$ & $13.38 \pm 6.85$ & $33.33 \pm 7.77$ & $53.57 \pm 22.87$ \\
\hline
\end{tabular}

$C D R$ clinical dementia ranking, MMSE Mini-Mental State Examination

${ }^{\dagger}$ Significant group difference between MCI due to AD and early-stage AD groups at a significance level of $p<0.01$

* Significant difference between the healthy control and MCI due to AD or early-stage AD groups by ANOVA at a significance level of $p<0.01$

healthy controls, $24.6 \pm 2.2$ for MCI due to AD subjects, and $22.2 \pm 2.9$ for early-stage AD subjects. Significant group differences were observed between healthy controls and MCI due to $\mathrm{AD}$ or early-stage $\mathrm{AD}$ subjects $(p<0.01)$. Furthermore, significant group differences between $\mathrm{MCI}$ due to $\mathrm{AD}$ and early-stage $\mathrm{AD}$ subjects at a significance level of $p<0.01$ were found.

\section{Preparation of Human Plasma}

Subjects were asked to provide a $10-\mathrm{mL}$ non-fasting venous blood sample (K3 EDTA, lavender-top tube). Each sample was blinded to colleagues in the laboratory. The blood samples were centrifuged ( $2500 \mathrm{~g}$ for $15 \mathrm{~min}$ ) within $1 \mathrm{~h}$ of draw, and plasma was aliquoted into cryotubes and stored at $-20^{\circ} \mathrm{C}$.

\section{Measurement of IMR Signals}

Plasma (40-60 $\mu \mathrm{L})$ was mixed with $80-60 \mu \mathrm{L}$ reagent at room temperature for the detection of an immunomagnetic reduction signal, IMR (\%). For each sample, IMR signal measurements were performed in duplicate. The IMR signals were converted into biomarker concentrations via standard curves. All plasma samples were blinded for IMR measurements.

\section{DISCUSSION}

\section{Consistency of IMR Signals Among Channels}

Tau-PBS samples (100-pg/mL) were used for IMR detection by the 36-channel SQUID-based ac magnetosusceptometer. The IMR signal of each channel is plotted in Fig. 6. The maximum IMR signal is $5.14 \%$, while the minimum IMR signal is $5.02 \%$. The mean value and the standard deviation of the 36 IMR signals are $5.07 \%$ and $0.03 \%$, respectively. The coefficient of variation in the 36 IMR signals is obtained as $0.62 \%$, revealing the high consistency in IMR signals among channels.

\section{Concentration-Dependent Biomarker IMR Signals}

Amyloid $\beta$ 1-42 (A $\left.\beta_{1-42}\right)(10 \mu \mathrm{L}$ of $0.1-\mathrm{mg} / \mathrm{mL})$ (Cat. no. A9810; SIGMA-ALDRICH,) was spiked into $9990 \mu \mathrm{L}$ of PBS (pH 7.4) to produce a $100 \mathrm{ng} / \mathrm{mL} \quad(=100,000 \mathrm{pg} / \mathrm{mL}) \quad \mathrm{A} \beta_{1-42}$-PBS stock-A sample. The stock-A sample $(100 \mu \mathrm{L})$ was spiked into a $9900-\mu \mathrm{L}$ PBS buffer pool to obtain a $1 \mathrm{ng} / \mathrm{mL} \quad(=1000 \mathrm{pg} / \mathrm{mL}) \quad \mathrm{A} \beta_{1-42}$-PBS stock-B sample. Stock-A and stock-B samples were mixed with $\mathrm{PBS}$ in various volume ratios to obtain nine $A \beta_{1-42}$-PBS samples of $1,10,50$, 


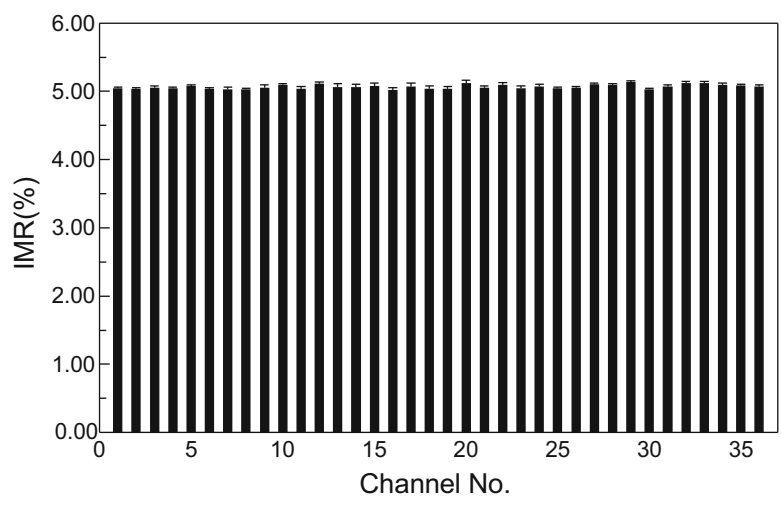

Fig. 6 Measured IMR signals of the 36-channel high-Tc SQUID ac magnetosusceptometer. The detected sample is $100-\mathrm{pg} / \mathrm{mL}$ Tau protein

$100,1000,2500,5000,20,000$, and 50,000 pg/ $\mathrm{mL}$, which were used for IMR measurements. The IMR signals of these nine $A \beta_{1-42}$-PBS samples are plotted with dots in Fig. 7. Clearly, Fig. 7 shows the IMR signal increases as $A \beta_{1-42}$ concentration increases.

The IMR signals in Fig. 7 for $A \beta_{1-42}$ concentrations from 1 to $50,000 \mathrm{pg} / \mathrm{mL}$ are used for exploring the analytic relationship, which follows the logistic function $[69,70]$

$$
\operatorname{IMR}(\%)=\left[\frac{A-B}{1+\left(\frac{\phi_{A \beta_{1}-42}}{\phi_{\mathrm{o}}}\right)^{\gamma}}+B\right] \times 100 \%
$$

where $A, B, \gamma$ and $\phi_{\mathrm{o}}$ are fitting parameters. By fitting the $A \beta_{1-42}$ concentration-dependent IMR signals in Fig. 7 to Eq. (18.1), the parameters are found to be $A=1.91, B=8.09, \gamma=0.49$ and $\phi_{\mathrm{o}}=14,157$. The parameter $\phi_{\mathrm{A} \beta 1-42}$ is the $\mathrm{A} \beta_{1-42}$ concentration. The fitted logistic function is plotted with a solid line in Fig. 7, with a coefficient of determination $\left(R^{2}\right)$ of 0.999 . Remarkably, significant IMR signals can could be detected for the $1-\mathrm{pg} / \mathrm{mL} A \beta_{1-42}$-PBS sample. This implies that the minimal detection limit of assaying $A \beta_{1-42}$ using IMR is on the $\mathrm{pg} / \mathrm{mL}$ level.

The IMR signal as a function of Tau-protein concentration from 1 to $5000 \mathrm{pg} / \mathrm{mL}$, i.e., IMR $(\%)-\phi_{\text {Tau }}$ curve, was measured. Samples of various concentrations of Tau protein were prepared by the following processes: $50 \mu \mathrm{L}$ of purified human Tau protein ladder with six

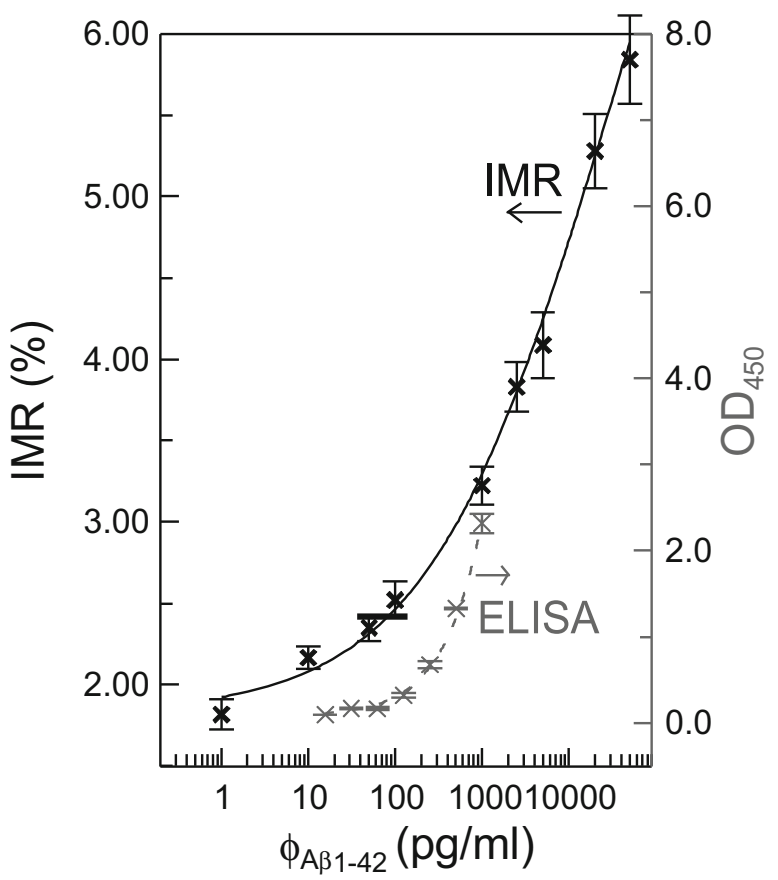

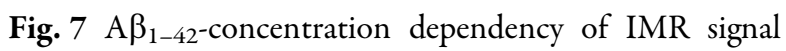
(solid line) and optical density (dashed line)

isoforms $(30 \mu \mathrm{g} / \mathrm{mL}$; Cat. no. T7951; SIGMA-ALDRICH) was mixed with $250 \mu \mathrm{L}$ of PBS (pH 7.4) to reach a final concentration of $5 \mu \mathrm{g} /$ $\mathrm{mL}$ Tau protein; $20 \mu \mathrm{L}$ of Tau protein solution $(5 \mu \mathrm{g} / \mathrm{mL})$ is spiked into a $9980-\mu \mathrm{L}$ PBS (pH 7.4) pool to reach a $10 \mathrm{ng} / \mathrm{mL} \quad(=10,000 \mathrm{pg} / \mathrm{mL})$ Tau-PBS stock-A sample; $1000 \mu \mathrm{L}$ of the stock-A sample was spiked into a $9000-\mu \mathrm{L}$ PBS pool to obtain a $1 \mathrm{ng} / \mathrm{mL} \quad(=1000 \mathrm{pg} / \mathrm{mL}) \quad$ Tau-PBS stock-B sample. Then, the stock-A and stock-B samples are mixed with PBS with various volume ratios to obtain Tau-PBS samples containing $0.1-2500 \mathrm{pg} / \mathrm{mL}$ of total Tau protein.

The detected IMR signals for Tau-PBS samples are plotted with crosses in Fig. 8. These experimental data are fitted to Eq. (7) by replacing $\phi_{\mathrm{A} \beta 1-42}$ with $\phi_{\text {Tau }}$. The values of the fitting parameters were found to be $A=2.28$, $B=7.34, \gamma=0.33$ and $\phi_{\mathrm{o}}=39.03$. The coefficient of determination $\left(R^{2}\right)$ was 0.999 . The fitted logistic function is plotted as the solid line in Fig. 8. Similar to the case in Fig. 7, the Tau-protein solution at $\mathrm{pg} / \mathrm{mL}$ provides a significant IMR signal. The low-detection limit of assaying Tau protein using IMR at the level of $\mathrm{pg} / \mathrm{ml}$. 


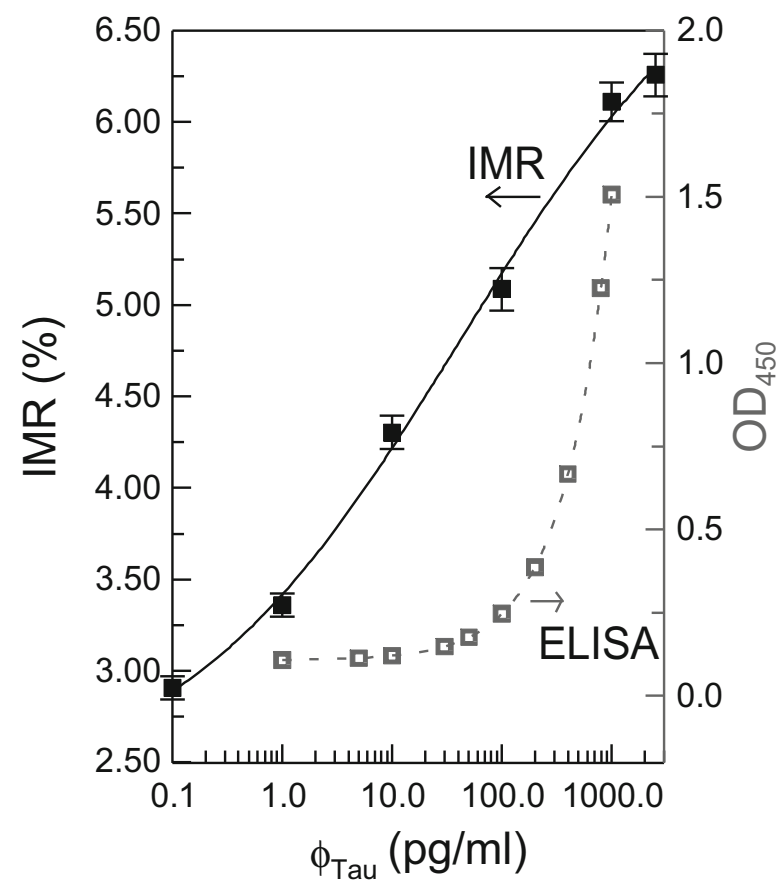

Fig. 8 Tau protein concentration dependency of IMR signal (solid line) and optical density (dashed line)

To reveal the ultra-high sensitivity of IMR, the $A \beta_{1-42}$ and Tau-protein concentration-dependent signals (OD450) were explored using the most frequently used laboratory assay, enzyme-linked immunosorbent assay (ELISA), which is plotted as dashed lines in Figs. 7 and 8 for $A \beta_{1-42}$ and Tau protein, respectively [59]. Clearly, for both $A \beta_{1-42}$ or Tau protein, the OD450 is trivial for concentrations lower than $100 \mathrm{pg} / \mathrm{mL}$. The results in Figs. 7 and 8 provide evidence that the IMR assays are much more sensitive than ELISA. Samples with $A \beta_{1-42}$ or Tau-protein concentrations at several tens of $\mathrm{pg} / \mathrm{mL}$ can be assayed with IMR, but not with ELISA.

\section{Interference Tests for IMR Assay on $\mathrm{A}_{1-42}$ and Tau Protein}

For human plasma, many kinds of chemical and biological molecules co-exist with $A \beta_{1-42}$ and Tau protein. It is necessary to investigate the interference of these molecules in the detection of $A \beta_{1-42}$ and Tau protein using IMR. Some typical molecules were selected as interfering materials and mixed with $A \beta_{1-42}$ or Tau protein. For the interference tests on $A \beta_{1-42}$, a sample of pure $100-\mathrm{pg} / \mathrm{mL} A \beta_{1-42}$ and samples of $100-\mathrm{pg} /$ $\mathrm{mL} \mathrm{A} \beta_{1-42}$ with either $1000-\mu \mathrm{g} / \mathrm{mL}$ hemoglobin, $600-\mu \mathrm{g} / \mathrm{mL}$ conjugated bilirubin, $30,000-\mu \mathrm{g} / \mathrm{mL}$ intra lipid, $200-\mu \mathrm{g} / \mathrm{mL}$ uric acid, $500-\mathrm{IU} / \mathrm{mL}$ rheumatoid factor, $60,000-\mu \mathrm{g} / \mathrm{mL}$ albumin, $500-\mu \mathrm{g} / \mathrm{mL}$ acetylsalicylic acid, $300-\mu \mathrm{g} / \mathrm{mL}$ ascorbic acid, $1000-\mu \mathrm{g} / \mathrm{mL}$ ampicillin sodium, $100-\mathrm{pg} / \mathrm{mL} \mathrm{A} \beta_{1-40}$, or $1000-\mathrm{ng} / \mathrm{mL}$ heterophilic antibody were assayed using IMR. The measured concentration of the pure $A \beta_{1-42}$ was $115.74 \mathrm{pg} /$ $\mathrm{mL}$. The detected $\mathrm{A} \beta_{1-42}$ concentrations of other samples with interfering materials ranged between 104.31 and $123.80 \mathrm{pg} / \mathrm{mL}$. The resulting recovery rates were $90.1 \%-108.7 \%$. According to the FDA guideline, the accepted recovery rate is $90 \%-110 \%$. Hence, there is no significant interference of these typical molecules with the assay of $A \beta_{1-42}$ using IMR.

For the interference tests on Tau protein, a sample of pure $100-\mathrm{pg} / \mathrm{mL}$ Tau protein and samples of $100-\mathrm{pg} / \mathrm{mL}$ Tau protein with either $1000-\mu \mathrm{g} / \mathrm{mL}$ hemoglobin, $600-\mu \mathrm{g} / \mathrm{mL}$ conjugated bilirubin, $30,000-\mu \mathrm{g} / \mathrm{mL}$ intra lipid, $200-\mu \mathrm{g} / \mathrm{mL}$ uric acid, $500-\mathrm{IU} / \mathrm{mL}$ rheumatoid factor, $\quad 60,000-\mu \mathrm{g} / \mathrm{mL}$ albumin, $\quad 500-\mu \mathrm{g} / \mathrm{mL}$ acetylsalicylic acid, $300-\mu \mathrm{g} / \mathrm{mL}$ ascorbic acid, $1000-\mu \mathrm{g} / \mathrm{mL}$ ampicillin sodium, or $1000-\mathrm{ng} / \mathrm{mL}$ heterophilic antibody were assayed using IMR. The measured concentration of the pure Tau protein was $99.85 \mathrm{pg} / \mathrm{mL}$. The detected Tau-protein concentrations of the other samples with interfering materials ranged between 91.67 and $108.51 \mathrm{pg} / \mathrm{mL}$. The resulting recovery rates were $91.8 \%-108.7 \%$. Hence, there is no significant interference of these typical molecules with the assay of Tau protein using IMR.

The reason for the high specificity of the IMR assay is discussed in Ref. [70]. Interference with the assay is partly caused by non-specific binding between antibodies and non-target molecules. Once non-target molecules associate with antibodies immobilized on magnetic nanoparticles, the IMR signal is detectable and a false positive occurs. According to the mechanism of IMR, the magnetic nanoparticle is rotating regardless of whether non-target or target molecules associate with the magnetic nanoparticles via antibodies. The bound 
molecule is experiencing the centrifugal force because of particle rotation. The strength of the centrifugal force can be enhanced by increasing the rotation frequency of the nanoparticles. This can be done by adjusting the frequency of the applied ac magnetic fields. The binding force between the antibodies and non-target molecules is weaker than that between antibodies and target molecules. Hence, by suitably adjusting the rotating frequency of the applied ac magnetic fields, the strength of the centrifugal force is manipulated to be higher than the binding force for non-target molecules, but lower than that of target molecules. Thus, the binding between antibodies and non-target molecules is broken, whereas the binding between antibodies and target molecules is maintained. Therefore, the interference of non-target molecules is inhibited in IMR.

\section{Assay of Plasma Biomarkers for Diagnosing Alzheimer's Dementia}

The IMR assay is applied to detect the concentrations of $A \beta_{1-42}$ and Tau protein in human plasma. According to the clinical diagnosis, there were 68 healthy controls, 24 subjects with $\mathrm{MCI}$ due to $\mathrm{AD}$, and 31 early-stage-AD subjects. $\mathrm{MCI}$ due to $\mathrm{AD}$ is the transition stage from health to early-stage AD [22, 24, 48]. Figure 9a gives the age-dependent $A \beta_{1-42}$ concentration for healthy controls and subjects suffering from either MCI due to AD or early-stage AD. Each point in Fig. 9 a denotes the $A \beta_{1-42}$ concentration of one subject. For healthy controls, the $\mathrm{A} \beta_{1-42}$ concentration in human plasma is $15.82 \pm 0.73 \mathrm{pg} / \mathrm{mL}$. Note that the plasma $\mathrm{A} \beta_{1-42}$ concentration (plotted with dots) in healthy controls truly exists below the low-detection limit of ELISA but above that of IMR. This explains why IMR is suitable for application to the assay of ultra-low-concentration biomarkers of $\mathrm{AD}$ in human plasma. Once subjects present with $\mathrm{MCI}$ due to $\mathrm{AD}$ or early-stage $\mathrm{AD}$, the concentration of plasma $A \beta_{1-42}$ (plotted with crosses) increases $(18.14 \pm 1.51 \mathrm{pg} / \mathrm{mL})$. A significant difference $(p<0.001)$ in plasma $\mathrm{A} \beta_{1-42}$ concentration between healthy controls and subjects is observed in Fig. 9a. Through
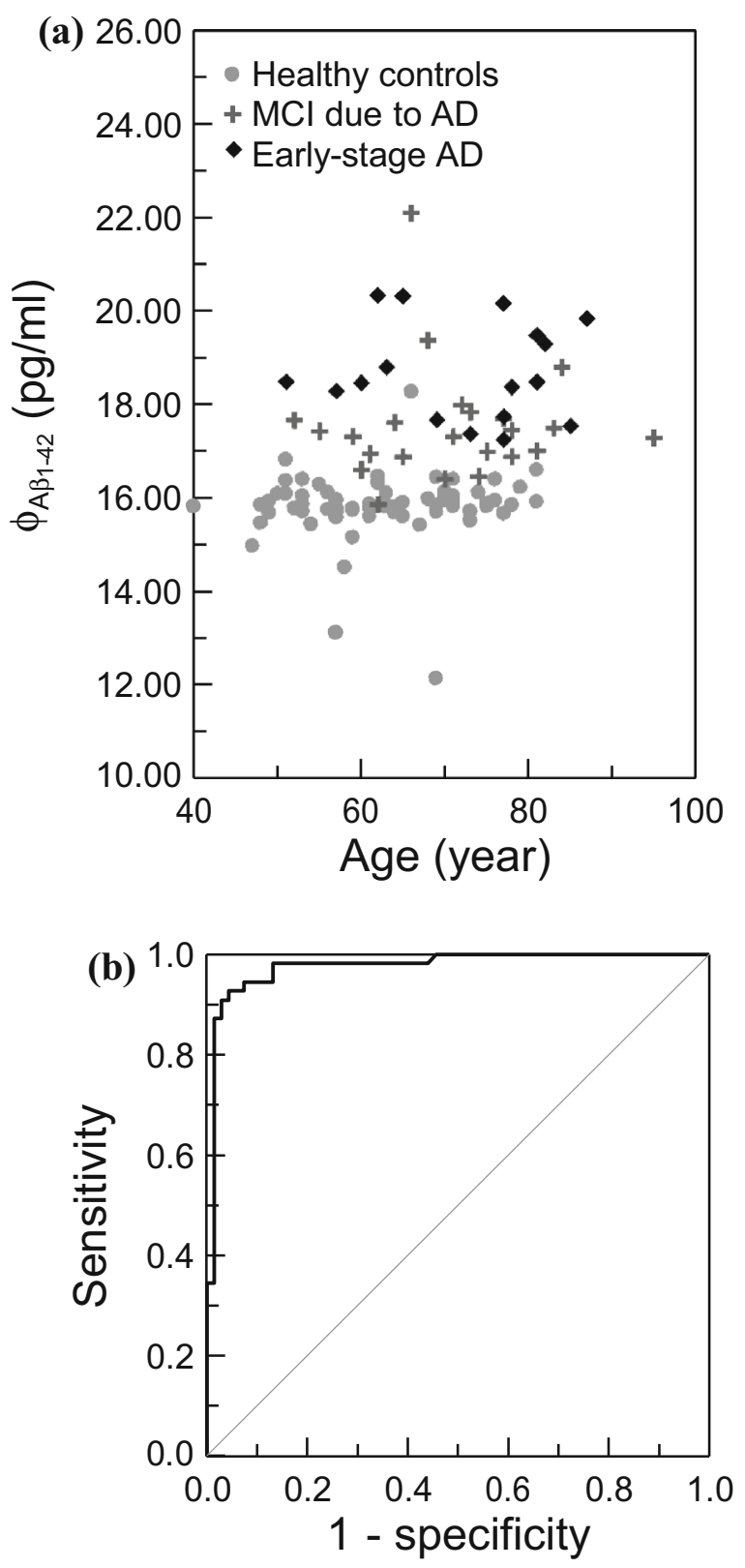

Fig. 9 a Age-dependent $A \beta_{1-42}$ concentration in human plasma of healthy controls and subjects with MCI due to $\mathrm{AD}$ or early-stage AD. Each data point denotes one subject. b ROC curve for discriminating healthy control and subjects with $\mathrm{MCI}$ due to $\mathrm{AD}$ or early-stage $\mathrm{AD}$ using plasma $A \beta_{1-42}$ concentration as a diagnostic parameter

analysis of the receiver operating characteristic (ROC) curve shown in Fig. 9b, the cut-off value of the plasma $A \beta_{1-42}$ concentration for discriminating subjects and healthy controls was found to be $16.42 \mathrm{pg} / \mathrm{mL}$. The corresponding 
Table 3 Cut-off value, clinical sensitivity, specificity, and area under the curve for discriminating healthy controls and AD subjects and for differentiating disease severity via ROC curve analysis using biomarker concentrations in human plasma

\begin{tabular}{llll}
\hline Plasma biomarker & Feature & $\begin{array}{l}\text { Healthy controls } \\
\text { vs. AD subjects }\end{array}$ & $\begin{array}{l}\text { MCI due to AD } \\
\text { vs. early-stage AD }\end{array}$ \\
\hline $\mathrm{A} \beta_{1-42}$ & Cut-off value & $16.41 \mathrm{pg} / \mathrm{mL}$ & $17.68 \mathrm{pg} / \mathrm{mL}$ \\
& Sensitivity & 0.945 & 0.742 \\
& Specificity & 0.926 & 0.750 \\
& AUC & 0.976 & 0.762 \\
Tau protein & Cut-off value & $25.20 \mathrm{pg} / \mathrm{mL}$ & $37.93 \mathrm{pg} / \mathrm{mL}$ \\
& Sensitivity & 0.964 & 0.742 \\
& Specificity & 0.956 & 0.792 \\
$\mathrm{~A} \beta_{1-42} \mathrm{XTau}$ protein & AUC & 0.993 & 0.822 \\
& Cut-off value & $455.49(\mathrm{pg} / \mathrm{mL})^{2}$ & $643.96(\mathrm{pg} / \mathrm{mL})^{2}$ \\
& Sensitivity & 0.945 & 0.774 \\
& Specificity & 0.971 & 0.837 \\
& AUC & 0.995 & 0.841 \\
\hline
\end{tabular}

$\mathrm{AD}$ subjects include those with $\mathrm{MCI}$ due to $\mathrm{AD}$ and early-stage $\mathrm{AD}$

$A U C$ area under the curve

clinical sensitivity and specificity were 0.945 and 0.926 , respectively. The area under the curve (AUC) was 0.976, as listed in Table 3.

As shown in Fig. 10a, using IMR, the detected concentration for the Tau protein in human plasma was $(13.38 \pm 6.85) \mathrm{pg} / \mathrm{mL}$ for healthy controls and $(40.74 \pm 13.72) \mathrm{pg} / \mathrm{mL}$ for subjects. An increase in plasma Tau protein in subjects with either MCI due to AD or early-stage AD was clearly observed. Through $t$ test analysis, the $p$ value in terms of concentration of plasma Tau protein differentiating healthy controls from subjects was smaller than 0.001, revealing a significant difference in the concentration of Tau protein in human plasma between subjects and healthy controls. According to analysis of the ROC shown in Fig. 10b, the cut-off value of plasma Tau-protein concentration for differentiating subjects with MCI due to AD or early-stage AD from healthy controls was found to be $25.20 \mathrm{pg} / \mathrm{mL}$. The corresponding clinical sensitivity and specificity were 0.964 and 0.956 , respectively. The AUC was 0.993, as listed in Table 3.

The results of $t$ test and ROC-curve analyses show the high consistency between the levels of plasma $A \beta_{1-42}$ and Tau protein and clinical diagnosis for discriminating healthy controls and subjects with early-stage AD or MCI due to AD. This implies a blood test via IMR is promising as an initial step before performing complicated and high-cost clinical diagnosis.

In the past, several research groups have applied ELISA or modified ELISA to assay plasma $\mathrm{A} \beta_{1-42}$ and Tau protein [71-76]. The results demonstrated no significant difference between healthy controls and $\mathrm{AD}$ subjects, possibly due to the ELISA technique's lack of ultra-sensitivity. The results shown in Figs. 9a and 10a evidence that the levels of plasma $A \beta_{1-42}$ and Tau protein are lower than $100 \mathrm{pg} / \mathrm{mL}$, which is below the low-detection limit of ELISA.

\section{Combined Plasma Biomarkers for Differentiating MCI due to AD from Early-Stage AD}

In addition to demonstrating the feasibility of differentiating healthy controls from AD subjects, the discrimination between MCI due to 

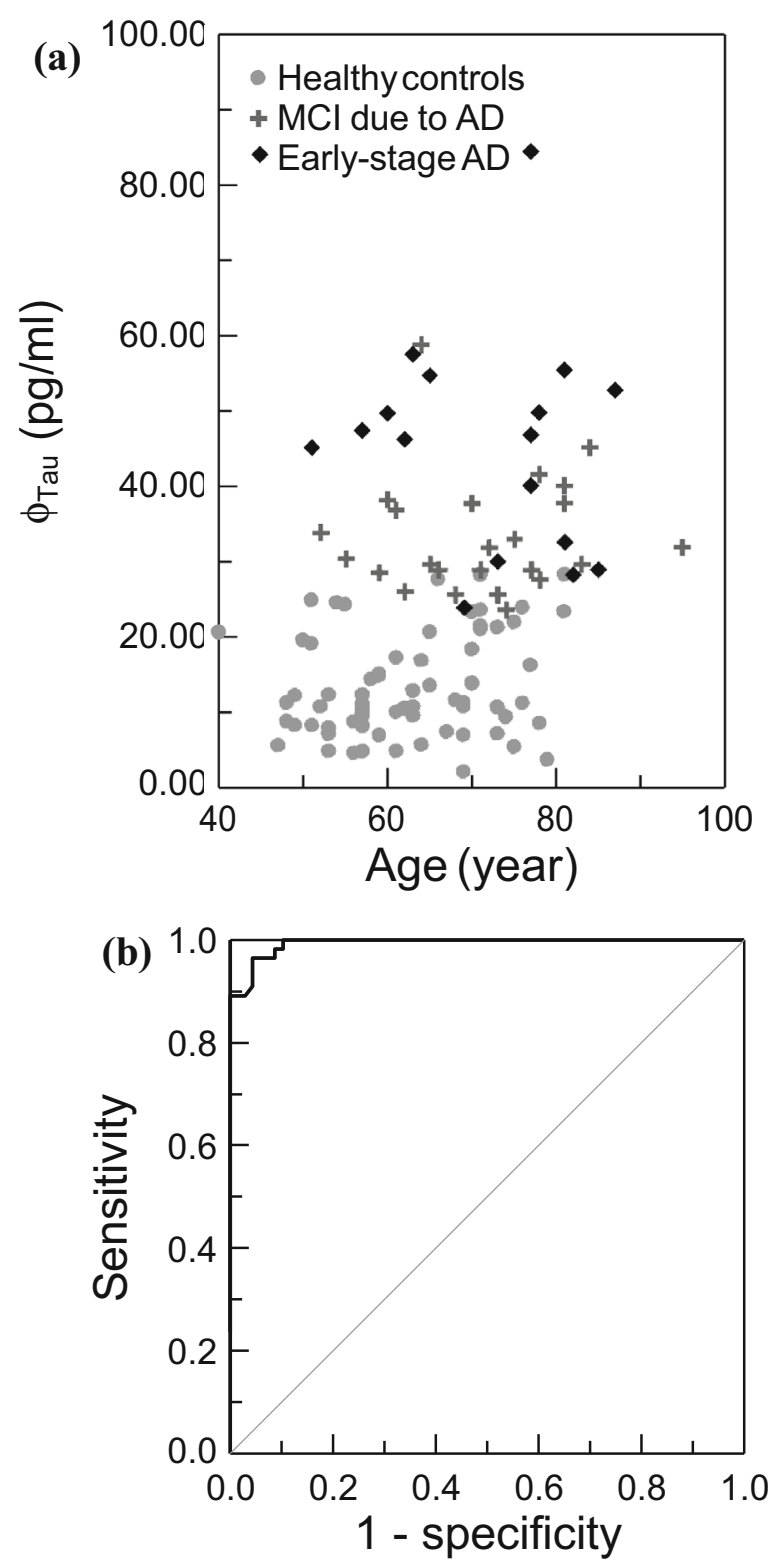

Fig. 10 a Age-dependent Tau protein concentration in human plasma of healthy controls and subjects with MCI due to $\mathrm{AD}$ or early-stage $\mathrm{AD}$. Each data point denotes one subject. b ROC curve for discriminating healthy controls and subjects with MCI due to AD or early-stage AD using plasma total Tau-protein concentration as a diagnostic parameter

AD from early-stage AD using plasma biomarkers was investigated. Remarkably, the subjects in this study with a high degree of AD severity showed lower scores on the MMSE. Hence, the relationship between plasma biomarker levels and MMSE score was investigated.
For plasma $A \beta_{1-42}$, the subjects with MCI due to $\mathrm{AD}$ showed a concentration of $(17.52 \pm 1.22)$ $\mathrm{pg} / \mathrm{mL}$, while $(18.61 \pm 1.55) \mathrm{pg} / \mathrm{mL}$ was found for subjects with early-stage AD. The $p$ value of the plasma $A \beta_{1-42}$ concentration between MCI due to $\mathrm{AD}$ and early-stage $\mathrm{AD}$ was calculated to be 0.003 , indicating a significant difference between $\mathrm{MCI}$ due to $\mathrm{AD}$ and early-stage $\mathrm{AD}$ when using plasma $A \beta_{1-42}$ as a diagnostic parameter. Through ROC analysis shown in Fig. 11a, the cut-off value to differentiate early-stage $\mathrm{AD}$ from $\mathrm{MCI}$ due to $\mathrm{AD}$ was $17.68 \mathrm{pg} /$ $\mathrm{mL}$. The clinical sensitivity and specificity were 0.742 and 0.750 , respectively. The area under the curve was 0.762 , as listed in Table 3 . These results reveal an accuracy of identifying disease severity of approximately $75 \%$ based on the $\mathrm{A} \beta_{1-42}$ plasma concentration.

Regarding the plasma Tau protein, subjects with MCI due to $\mathrm{AD}$ and early-stage $\mathrm{AD}$ showed concentrations of $(33.33 \pm 7.77) \mathrm{pg} / \mathrm{mL}$ and $(53.57 \pm 22.87) \mathrm{pg} / \mathrm{mL}$, respectively. A clear increase in the concentration of plasma Tau protein for early-stage $\mathrm{AD}$ compared to $\mathrm{MCI}$ due to $\mathrm{AD}$ resulted. The $p$ value in terms of plasma Tau-protein concentration for these two groups was calculated to be smaller than 0.001, showing a definite difference in plasma Tau-protein concentration between $\mathrm{MCI}$ due to $\mathrm{AD}$ and early-stage $\mathrm{AD}$. By performing ROC analysis shown in Fig. 11b, the cut-off value of Tau-protein concentration to discriminate MCI due to AD and early-stage AD was $37.93 \mathrm{pg} / \mathrm{mL}$. The clinical sensitivity and specificity were 0.742 and 0.792 , respectively. The area under the curve was 0.822. Compared to plasma $\mathrm{A} \beta_{1-42}$, plasma Tau protein showed higher accuracy in determining disease severity for prodromal AD. This suggests that plasma Tau protein is a promising biomarker not only to discriminate healthy controls and $\mathrm{AD}$ subjects but also to identify disease severity for prodromal AD. However, according to published papers [70, 77-80], elevations of Tau protein in CSF were found for other types of neurodegenerative diseases, such as Parkinson's disease, frontotemporal dementia, vascular dementia, and brain injuries. The degree of specificity of Tau protein to $\mathrm{AD}$ is not high enough. If Tau protein were to be used as the sole parameter for 

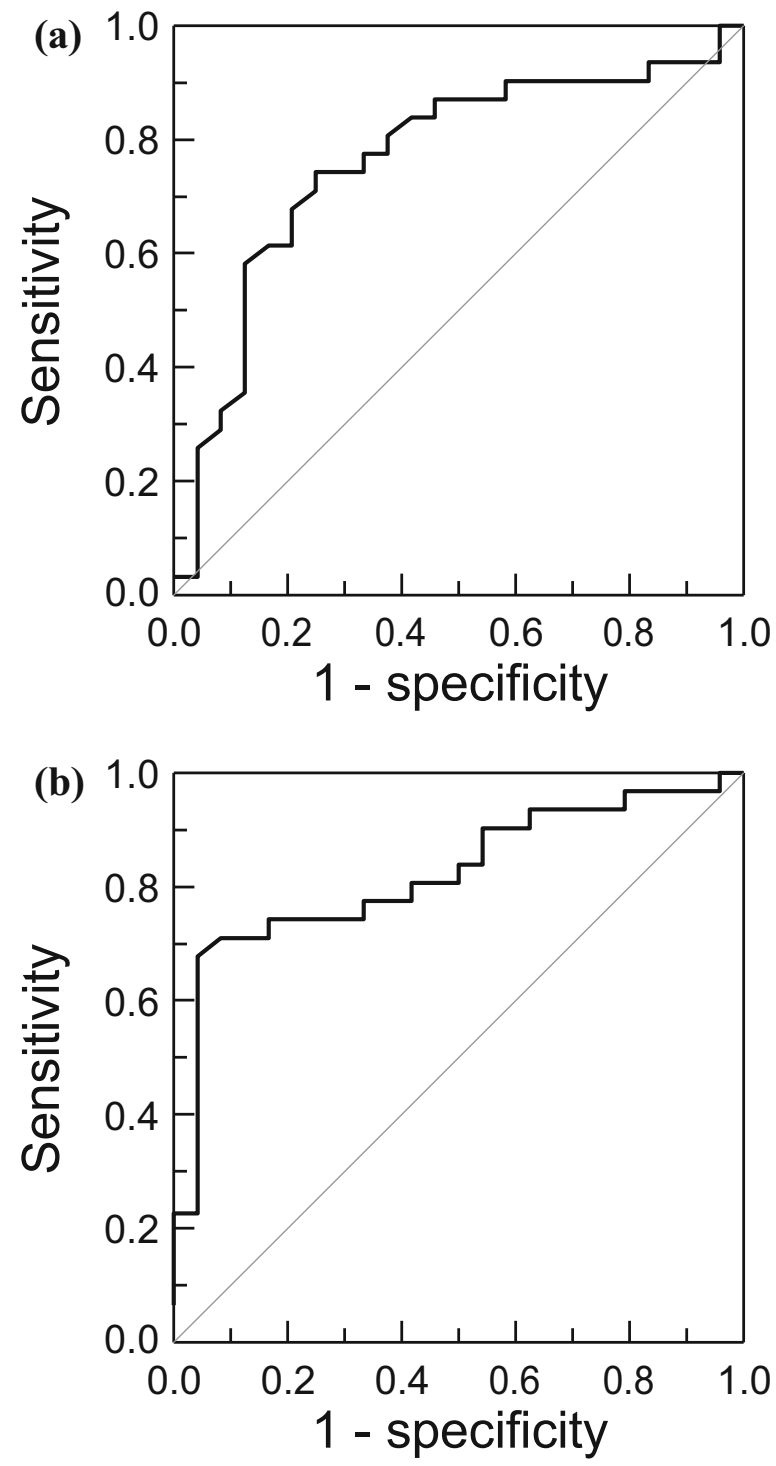

Fig. 11 ROC curve for discriminating $M C I$ due to $A D$ from early-stage $A D$ using a plasma $A \beta_{1-42}$ and $\mathbf{b}$ plasma Tau protein as a diagnostic parameter

diagnosing prodromal $\mathrm{AD}$, the false-positive occurrence due to other types of dementia or brain injuries would be more than negligible. Fortunately, $A \beta_{1-42}$ is highly correlated to the pathology of $A D$. $A \beta_{1-42}$ should be considered a parameter for diagnosing prodromal AD. To achieve high specificity and accuracy, the combination of $A \beta_{1-42}$ and Tau protein is suggested as a possible biomarker. In Figs. 9a and $10 \mathrm{a}$, the levels of $A \beta_{1-42}$ and Tau protein become higher for $\mathrm{AD}$ subjects. To enhance the

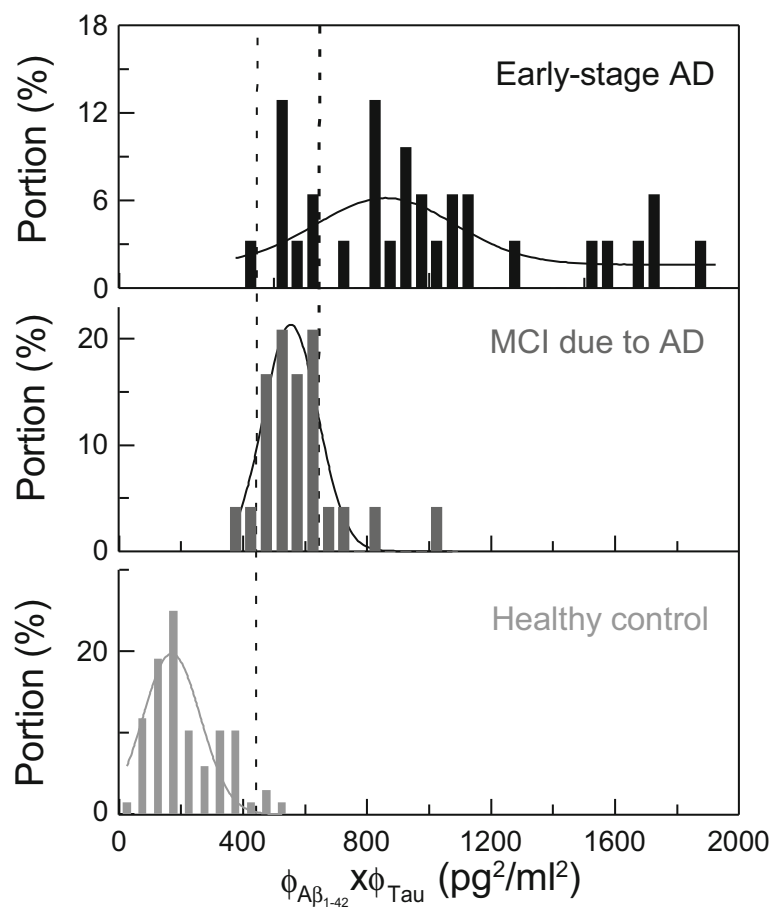

Fig. 12 Distributions of the concentration measurements of $\mathrm{A} \beta_{1-42}$ and Tau protein in human plasma of healthy controls and subjects with MCI due to AD or early-stage $\mathrm{AD}$. Each data point denotes one subject

increased biomarker level, the product of $A \beta_{1-42}$ concentration and Tau-protein concentration, denoted as $\phi_{\mathrm{A} \beta 1-42} \mathrm{X} \phi_{\mathrm{Tau}}$, is proposed as a diagnostic parameter [49]. The distributions of $\phi_{\mathrm{A} \beta 1-42} \mathrm{X} \phi_{\text {Tau }}$ for healthy controls, MCI due to $\mathrm{AD}$, and early-stage $\mathrm{AD}$ are plotted in Fig. 12. The solid lines in Fig. 12 denote the Gaussian distribution.

Figure 12 clearly shows that the values of $\phi_{\mathrm{A} \beta 1-42} \mathrm{X} \phi_{\text {Tau }}$ for healthy controls range between zero and $400(\mathrm{pg} / \mathrm{mL})^{2}$. The $\phi_{\mathrm{A} \beta 1-42} \mathrm{X} \phi_{\text {Tau }}$ values increase for MCI due to $\mathrm{AD}$ and are much higher for early-stage $\mathrm{AD}$. Obviously, $\phi_{\mathrm{A} \beta 1-42}$ $\mathrm{x} \phi_{\text {Tau }}$ is promising as a diagnostic parameter not only for discriminating AD subjects but also for identifying disease severity. In this study, MMSE scores decreased with disease severity. Hence, $\phi_{\mathrm{A} \beta 1-42} \mathrm{X} \phi_{\text {Tau }}$ increased with decreasing MMSE score for subjects in this study. Through analysis of the ROC shown in Fig. 13a, the cut-off value for discriminating healthy controls and AD subjects was found to be $455.49(\mathrm{pg} / \mathrm{mL})^{2}$, with the corresponding clinical sensitivity and 

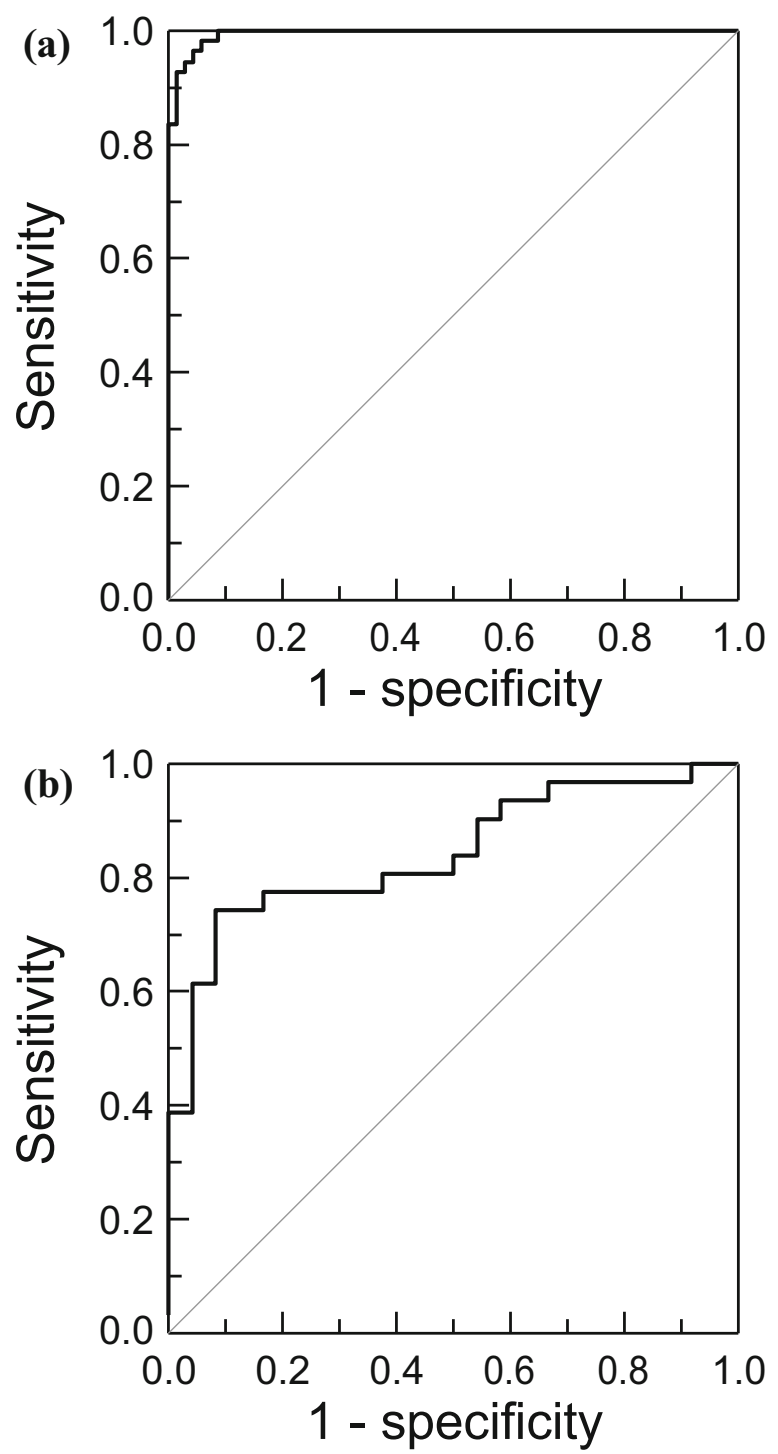

Fig. 13 ROC curve using the concentration measurements of $A \beta_{1-42}$ and $T a u$ protein in human plasma to discriminate a healthy controls from $\mathrm{AD}$ subjects, and b $\mathrm{MCI}$ due to $\mathrm{AD}$ from early-stage $\mathrm{AD}$

specificity being 0.945 and 0.971 , respectively. The area under the curve was 0.995 . The cut-off value is plotted with a thinly dashed line in Fig. 12. On the other hand, the cut-off value for differentiating early-stage AD from MCI due to $\mathrm{AD}$ was obtained as $643.96(\mathrm{pg} / \mathrm{mL})^{2}$ via the ROC analysis shown in Fig. 13b. The clinical sensitivity and specificity and area under the curve were $0.774,0.837$, and 0.841 , respectively.
This implies an accuracy of determining the severity of prodromal AD of nearly $85 \%$, which is absolutely applicable in clinics.

\section{CONCLUSIONS AND OUTLOOK}

Immunomagnetic reduction (IMR) is an assay technology involving the use of antibody-functionalized magnetic nanoparticles and a high-Tc SQUID-based ac magnetosusceptometer. When applying SQUID-based IMR to detect the biomarkers $\left(A \beta_{1-42}\right.$ and Tau protein) related to Alzheimer's disease (AD), the low-detection limits are at the $\mathrm{pg} / \mathrm{mL}$ level. Such a high-sensitivity assay makes it possible to quantitatively detect ultra-low concentrations of $A \beta_{1-42}$ and Tau protein in human plasma. One hundred and twenty-three subjects, including healthy controls, those with $\mathrm{MCI}$ due to $\mathrm{AD}$, and early-stage $\mathrm{AD}$ subjects, were enrolled for plasma tests of $A \beta_{1-42}$ and Tau protein using IMR. The results showed an accuracy of determining the severity of prodromal $\mathrm{AD}$ of nearly $85 \%$ by determining the concentration levels of $A \beta_{1-42}$ and total Tau protein in human plasma. Therefore, technically, SQUID-based IMR is suitable for screening early-stage Alzheimer's disease. SQUID-based IMR is a blood test, which is low-cost, low-risk, simple, and highly acceptable. These advantages are critical for the large-scale diagnosis of early-stage AD. Concerning future large-scale diagnosis, the throughput of the 36-channel analyzer would be a bottleneck. An updated version of the analyzer with tripled throughput is under development. Additionally, the detection of plasma $A \beta_{1-42}$ and total Tau protein using SQUID-based IMR for global cohorts is necessary, and the authors have been collaborating with groups in the US and Sweden. The detected concentrations of plasma $\mathrm{A} \beta_{1-42}$ or total Tau protein show a high consistency among cohorts from Taiwan, the US and Sweden, and the collaboration has now extended to Japan and Germany.

\section{ACKNOWLEDGEMENTS}

No funding or sponsorship was received for this study or publication of this article. All named 
authors meet the International Committee of Medical Journal Editors (ICMJE) criteria for authorship of this manuscript, take responsibility for the integrity of the work as a whole, and have given final approval for the version to be published.

Disclosures. Shieh-Yueh Yang is an employee of MagQu Co., Ltd., receives a salary from MagQu, and holds MagQu stock. Herng-Er Horng also holds MagQu stock. Ming-Jang Chiu and Ta-Fu Chen have nothing to disclose.

Compliance with Ethics Guidelines. This article is based on previously conducted studies and does not involve any new studies of human or animal subjects performed by any of the authors.

Data Availability. Data sharing is not applicable to this article as no datasets were generated or analyzed during the current study.

Open Access. This article is distributed under the terms of the Creative Commons Attribution-NonCommercial 4.0 International License (http://creativecommons.org/licenses/ by-nc/4.0/), which permits any noncommercial use, distribution, and reproduction in any medium, provided you give appropriate credit to the original author(s) and the source, provide a link to the Creative Commons license, and indicate if changes were made.

\section{REFERENCES}

1. Katzman R. The prevalence and malignancy of Alzheimer disease: a major killer. Arch Neurol. 1976;33:217-8.

2. Rocca WA, Petersen RC, Knopman DS, Hebert LE, Evans DE, Hall KS, Gao S, Unverzagt FW, Langa KM, Larson EB, White LR. Trends in the incidence and prevalence of Alzheimer's disease, dementia, and cognitive impairment in the United States. Alzheimer's Dementia. 2011;7:80-93.

3. https://www.alz.co.uk/research/statistics.
4. Alzheimer's Association. Alzheimer's disease facts and figures. Alzheimer's Dementia. $2015 ; 11: 332-84$.

5. Stefanacci RG. The costs of Alzheimer's disease and the value of effective therapies. Am J Manag Care. 2011;17:S356-62.

6. Bloom BS, de Pouvourville N, Straus WL. Cost of illness of Alzheimer's disease: how useful are current estimates? Gerontologist. 2003;43:158-64.

7. Reiman EM, Langbaum JBS, Fleisher AS, Caselli RJ, Chen K, Ayutyanont N, Quiroz YT, Kosik KS, Lopera $\mathrm{F}$, Tariot PN. Alzheimer's prevention initiative: a plan to accelerate the evaluation of presymptomatic treatments. J Alzheimer's Dis. 2011;26:321-9.

8. Petersen RC, Aisen PS, Beckett LA, Donohue MC, Gamst AC, Harvey DJ, Jack CR, Jagust WJ, Shaw LM, Toga AW, Trojanowski JQ, Weiner MW. Alzheimer's disease neuroimaging initiative (ADNI). Neurology. 2010;74:201-9.

9. Kivipelto M, Solomon A, Ahtiluoto S, Ngandu T, Lehtisalo J, Antikainen R, Hänninen LBT, Jula A, Laatikainen T, Lindström J, Mangialasche F, Nissinen A, Paajanen T, Pajala S, Peltonen M, Rauramaa R, Stigsdotter-Neely A, Strandberg T, Tuomilehto J, Soininen $\mathrm{H}$. The finnish geriatric intervention study to prevent cognitive impairment and disability (FINGER): study design and progress. Alzheimer's Dementia. 2013;9:657-65.

10. Hardy JA, Higgins GA. Alzheimer's disease: the amyloid cascade hypothesis. Science. 1992;256:184-5.

11. Hyman BT, Phelps $\mathrm{CH}$, Beach TG, Bigio EH, Cairns NJ, Carrillo MC, Dickson DW, Duyckaerts C, Frosch MP, Masliah E, Mirra SS, Nelson PT, Schneider JA, Thal DR, Thies B, Trojanowski JQ, Vinters HV, Montine TJ. National institute on aging-Alzheimer's association guidelines for the neuropathologic assessment of Alzheimer's disease. Alzheimer's Dementia. 2012;8:1-13.

12. Leinonen V, Koivisto AM, Savolainen S, Rummukainen J, Tamminen JN, Tillgren T, Vainikka S, Pyykkö OT, Mölsä J, Fraunberg M, Pirttilä T, Jääskeläinen JE, Soininen H, Rinne J, Alafuzoff I. Amyloid and tau proteins in cortical brain biopsy and Alzheimer's disease. Ann Neurol. 2010;68:446-53.

13. Holm A, Savolainen S, Alafuzoff I. Brain biopsy prior to treatment of Alzheimer's disease. Minim Invasive Neurosurg. 2003;46:161-4.

14. Goate A, Chartier-Harlin MC, Mullan M, Brown J, Crawford F, Fidani L, Giuffra L, Haynes A, Irving N, James L, Mant R, Newton P, Rooke K, Roques P, 
Talbot C, Pericak-Vance M, Roses A, Williamson R, Rossor M, Owen M, Hardy J. Segregation of a missense mutation in the amyloid precursor protein gene with familial Alzheimer's disease. Nature. 1991;349:704-6.

15. Crews L, Masliah E. Molecular mechanisms of neurodegeneration in Alzheimer's disease. Hum Mol Genet. 2010;19:R12-20.

16. Huang Y, Mucke L. Alzheimer mechanisms and therapeutic strategies. Cell. 2012;148:1204-22.

17. Tomlinson BE, Blessed G, Roth M. Observations on the brains of demented old people. J Neurol Sci. 1970;11:205-42.

18. Iqbal GIK, Quinlan M, Tung YC, Zaidi MS, Wisniewski HM. Microtubule-associated protein tau: a component of Alzheimer paired helical filaments. J Biol Chem. 1986;261:6084-9.

19. Arrigada PA, Growdon JH, Hedley-White ET, Hyman BT. Neurofibrillary tangles but not senile plaques parallel duration and severity of Alzheimer's disease. Neurology. 1992;42:631-9.

20. de Calignon A, Polydoro M, Suárez-Calvet M, William C, Adamowicz DH, Kopeikina KJ, Pitstick R, Sahara N, Ashe KH, Carlson GA, Spires-Jones TL, Hyman BT. Propagation of tau pathology in a model of early Alzheimer's disease. Neuron. 2012;73:685-97.

21. Henneman WJP, Sluimer JD, Barnes J, van der Flier WM, Sluimer IC, Fox NC, Scheltens P, Vrenken H, Barkhof F. Hippocampal atrophy rates in Alzheimer disease. Neurology. 2009;72:999-1007.

22. Chiu MJ, Chen YF, Chen TF, Yang SY, Yang FP, Tseng TW, Chieh JJ, Chen JC, Tzen KY, Hua MS, Horng HE. Plasma tau as a window to the brainnegative associations with brain volume and memory function in mild cognitive impairment and early Alzheimer's disease. Hum Brain Mapp. 2014;35:3132-42.

23. Johnson KA, Minoshima S, Bohnen NI, Donohoe KJ, Foster NL, Herscovitch P, Karlawish JH, Rowe CC, Carrillo MC, Hartley DM, Hedrick S, Mitchell K, Pappas V, Thies WH. Appropriate use criteria for amyloid PET. Alzheimer's Dementia. 2013;9:e-1--16.

24. Tzen KY, Yang SY, Chen TF, Cheng TW, Horng HE, Wen HP, Huang YY, Shiue CY, Chiu MJ. Plasma A $\beta$ but not tau related to brain $\mathrm{PiB}$ retention in early Alzheimer's disease. ACS Chem Neurosci. 2014;5:830-6.

25. O'Brien JT, Herholz K. Amyloid imaging for dementia in clinical practice. BMC Med. 2015;13:163-1-3.
26. Okamura N, Harada R, Furumoto S, Arai H, Yanai K, Kudo Y. Tau PET imaging in Alzheimer's disease. Curr Neurol Neurosci Rep. 2014;14:500-6.

27. Brier MR, Gordon B, Friedrichsen $\mathrm{K}$, McCarthy J, Stern A, Christensen J, Owen C, Aldea P, Su Y, Hassenstab J, Cairns NJ, Holtzman DM, Fagan AM, Morris JC, Benzinger TLS, Ances BM. Tau and A $\beta$ imaging, CSF measures, and cognition in Alzheimer's disease. Sci Trans Med. 2016;8:338aa66.

28. Vemuri P, Jack CR Jr. Role of structural MRI in Alzheimer's disease. Alzheimer's Res Ther. 2010;2:23-1--10.

29. Williams SCP. Alzheimer's disease: mapping the brain's decline. Nature. 2013;502:S84-5.

30. Schuff N, Woerner N, Boreta L, Kornfield T, Shaw LM, Trojanowski JQ, Thompson PM, Jack CR Jr, Weiner MW. MRI of hippocampal volume loss in early Alzheimer's disease in relation to ApoE genotype and biomarkers. Brain. 2009;132:1067-77.

31. McKhann G, Drachman D, Folstein M, Katzman R, Price D, Stadlan EM. Clinical diagnosis of Alzheimer's disease. Neurology. 1984;34:939-44.

32. Moms JC, Heyman A, Mohs RC, Hughes JP, van Belle G, Fillenbaum G, Mellits ED, Clark DC. The consortium to establish a registry for Alzheimer's disease (CERAD). Neurology. 1989;39:1159-65.

33. Tierney MC, Yao C, Kiss A, McDowell I. Neuropsychological tests accurately predict incident Alzheimer disease after 5 and 10 years. Neurology. 2005;64:1853-9.

34. Braaten AJ, Parsons TD, McCue R, Sellers A, Burns WJ. Neurocognitive differential diagnosis of dementing diseases: alzheimer's dementia, vascular dementia, frontotemporal dementia, and major depressive disorder. Int J Neurosci. 2006;116:1271-93.

35. Chapman RM, Mapstone $\mathrm{M}$, Porsteinsson AP, Gardner MN, McCrary JW, DeGrush E, Reilly LA, Sandoval TC, Guillily MD. Diagnosis of Alzheimer's disease using neuropsychological testing improved by multivariate analyses. J Clin Exp Neuropsychol. 2010;32:793-808.

36. Weintraub S, Wicklund AH, Salmon DP. The neuropsychological profile of Alzheimer disease. Cold Spring Harb Perspect Med. 2012;2:006171-1--18.

37. Mawuenyega KG, Sigurdson W, Ovod V, Munsell L, Kasten T, Morris JC, Yarasheski KE, Bateman RJ. Decreased clearance of CNS amyloid- $\beta$ in Alzheimer's disease. Science. 2010;330:1774-7. 
38. Bard F, Cannon C, Barbour R, Burke RL, Games D, Grajeda H, Guido T, Hu K, Huang J, Johnson-Wood K, Khan K, Kholodenko D, Lee M, Lieberburg I, Motter R, Nguyen M, Soriano F, Vasquez N, Weiss K, Welch B, Seubert P, Schenk D, Yednock T. Peripherally administered antibodies against amyloid $\beta$-peptide enter the central nervous system and reduce pathology in a mouse model of Alzheimer disease. Nat Med. 2000;6:916-9.

39. Andreasen N, Minthon L, Davidsson P, Vanmechelen E, Vanderstichele H, Winblad B, Blennow K. Evaluation of CSF-tau and CSF-A $\beta 42$ as diagnostic markers for Alzheimer disease in clinical practice. Arch Neurol. 2001;58:373-9.

40. Kim WH, Lee S, Hall GF. Secretion of human tau fragments resembling CSF-tau in Alzheimer's disease is modulated by the presence of the exon 2 insert. FEBC Lett. 2010;584:3085-8.

41. Tapiola T, Alafuzoff I, Herukka SK, Parkkinen L, Hartikainen P, Soininen H, Pirttilä T. Cerebrospinal fluid $\beta$-amyloid 42 and tau proteins as biomarkers of Alzheimer-type pathologic changes in the brain. Arch Neurol. 2009;66:382-9.

42. Andreasen N, Hesse C, Davidsson P, Minthon L, Wallin A, Winblad B, Vanderstichele H, Vanmechelen E, Blennow K. Cerebrospinal fluid beta-amyloid(1-42) in Alzheimer disease: differences between early- and late-onset Alzheimer disease and stability during the course of disease. Arch Neurol. 1999;56:673-80.

43. Hölttä $M$, Hansson $\mathrm{O}$, Andreasson U, Hertze J, Minthon L, Nägga K, Andreasen N, Zetterberg $\mathrm{H}$, Blennow K. Evaluating amyloid- $\beta$ oligomers in cerebrospinal fluid as a biomarker for Alzheimer's disease. PLoS One. 2013;8:e66381.

44. Dumurgier J, Schraen S, Gabelle A, Vercruysse O, Bombois S, Laplanche JL, Peoch K, Sablonnière B, Kastanenka KV, Delaby C, Pasquier F, Touchon J, Hugon J, Paquet C, Lehmann S. Cerebrospinal fluid amyloid- $\beta 42 / 40$ ratio in clinical setting of memory centers: a multicentric study. Alzheimer's Res Ther. 2015;7:30-1-9.

45. Anoop A, Singh PK, Jacob RS, Maji SK. CSF biomarkers for Alzheimer's disease diagnosis. Int J Alzheimer's Dis. 2010. doi:10.4061/2010/606802.

46. Mattsson N, Insel PS, Landau S, Jagust W, Donohue M, Shaw LM, Trojanowski JQ, Zetterberg H, Blennow K, Weiner M. Diagnostic accuracy of CSF A $\beta 42$ and florbetapir PET for Alzheimer's disease. Ann Clin Transl Neurol. 2014;1:534-43.

47. Lautner R, Palmqvist S, Mattsson N. Apolipoprotein E genotype and the diagnostic accuracy of cerebrospinal fluid biomarkers for Alzheimer disease. JAMA Psychiatry. 2014;71:1183-91.

48. Chiu MJ, Yang SY, Chen TF, Chieh JJ, Huang TZ, Yip PK, Yang HC, Cheng TW, Chen YF, Hua MS, Horng HE. New assay for old markers-plasma beta amyloid of mild cognitive impairment and Alzheimer's disease. Curr Alzheimer's Res. 2012;9:1142-8.

49. Chiu MJ, Yang SY, Horng HE, Yang CC, Chen TF, Chieh JJ, Chen HH, Chen TC, Ho CS, Chang SF, Liu $\mathrm{HC}$, Hong CY, Yang HC. Combined plasma biomarkers for diagnosing mild cognition impairment and Alzheimer's disease. ACS Chem Neurosci. 2013;4:1530-6.

50. Sehlin D, Sölvander S, Paulie S, Brundin R. Interference from heterophilic antibodies in amyloid-beta oligomer ELISAs. J Alzheimer's Dis. 2010;21:1295-301.

51. Azriel R, Gaz E. Analysis of the minimal amyloid-forming fragment of the islet amyloid polypeptide. J Biol Chem. 2001;276:34156-61.

52. Trysberg E, Höglund K, Svenungsson E, Blennow K, Tarkowski A. Decreased levels of soluble amyloid $\beta$-protein precursor and $\beta$-amyloid protein in cerebrospinal fluid of patients with systemic lupus erythematosus. Arthritis Res Ther. 2004;6:R129-36.

53. Hong CY, Wu CC, Chiu YC, Yang SY, Horng HE, Yang HC. Magnetic susceptibility reduction method for magnetically labeled immunoassay. Appl Phys Lett. 2006;88:212512-1-3.

54. Chieh JJ, Yang SY, Jian ZF, Wang WC, Horng HE, Yang HC, Hong CY. Hyper-high-sensitivity wash-free magnetoreduction assay on biomolecules using high-Tc superconducting quantum interference devices. J Appl Phys. 2008;103:014703-1-6.

55. Jiang W, Yang HC, Yang SY, Horng HE, Hung JC, Chen YC, Hong CY. Preparation and properties of superparamagnetic nanoparticles with narrow size distribution and biocompatible. J Magn Magn Mater. 2004;283:210-4.

56. Huang KW, Yang SY, Yu CY, Chieh JJ, Yang CC, Horng HE, Hong CY, Yang HC, Wu CC. Exploration of the relationship between the tumor burden and the concentration of vascular endothelial growth factor in liver-cancer-bearing animals using immunomagnetic reduction assay. J Biomed Nanotechnol. 2011;7:535-41.

57. Yang SY, Chiu MJ, Lin CH, Horng HE, Yang CC, Chieh JJ, Chen HH, Liu BH. Development of an ultra-high sensitive immunoassay with plasma biomarker for differentiating Parkinson disease dementia from Parkinson disease using antibody 
functionalized magnetic nanoparticles. J Nanobiotechnol. 2016;14:41-7.

58. Yang SY, Chieh JJ, Wang WC, Yu CY, Lan CB, Chen $\mathrm{JH}$, Horng HE, Hong CY, Yang HC. Ultra-highly sensitive and wash-free bio-detections for H5N1 virus via magnetoreduction assays. J Virol Methods. 2008;153:250-2.

59. Mondello S, Buki A, Barzo P, Randall J, Provuncher G, Hanlon D, Wilson D, Kobeissy F, Jeromin A. CSF and plasma amyloid- $\beta$ temporal profiles and relationships with neurological status and mortality after severe traumatic brain injury. Sci Rep. 2014;4:6446-1-6.

60. Janelidze S, Stomrud E, Palmgvist S, Zetterberg H, van Western D, Jeromin A, Song L, Hanlon D, Hehir CAT, Baker D, Blennow K, Hasson O. Plasma $\beta$-amyloid in Alzheimer's disease and vascular disease. Sci Rep. 2016;6:26801-1--11.

61. Todd J, Freese B, Lu A, Held D, Morey J, Livingston $\mathrm{R}$, Goix P. Ultrasensitive flow-based immunoassays using single-molecule counting. Clin Chem. 2007;53:1990-5.

62. Apple FS, Steffen LM, Pearce LA, Murakami MM, Luepker RV. Increased cardiac troponin I as measured by a high-sensitivity assay is associated with high odds of cardiovascular death: the Minnesota heart survey. Clin Chem. 2012;58:930-5.

63. Horng HE, Yang SY, Huang YW, Jiang W, Hong CY, Yang HC. Nanomagnetic particles for SQUID-based magnetically labeled immunoassay. IEEE Trans Appl Supercond. 2005; 15:668-71.

64. Frenkel J. Theory of liquid. New York: Dover; 1955.

65. Brown WF Jr. Thermal fluctuations of a single-domain particle. Phys Rev. 1963;130:1677-86.

66. Yang CC, Yang SY, Chen HH, Weng WL, Horng HE, Chieh JJ, Hong CY, Yang HC. Effect of molecule-particle binding on the reduction in the mixed-frequency alternating current magnetic susceptibility of magnetic bio-reagents. J Appl Phys. 2012;112:024704-1-4.

67. Chieh JJ, Yang SY, Horng HE, Yu CY, Lee CL, Wu $\mathrm{HL}$, Hong CY, Yang HC. Immunomagnetic reduction assay using high-Tc superconducting-quantum-interference-device-based magnetosusceptometry. J Appl Phys. 2010;107:074903-1-5.

68. Yang SY, Chieh JJ, Yang CC, Liao SH, Chen HH, Horng HE, Yang HC, Hong CY, Chiu MJ, Chen TF, Huang KW, Wu CC. Clinic applications in assaying ultra-low-concentration bio-markers using HTS SQUID-based AC magnetosusceptometer. IEEE Trans Appl Supercond. 2013;23:1600604-7.
69. Yang CC, Yang SY, Chieh JJ, Horng HE, Hong CY, Yang HC. Universal behavior of biomolecule-concentration-dependent reduction in AC magnetic susceptibility of bioreagents. IEEE Magn Lett. 2012;3:1500104-1-4.

70. Yang CC, Yang SY, Chieh JJ, Horng HE, Hong CY, Yang HC, Chen KH, Shih BY, Chen TF, Chiu MJ. Biofunctionalized magnetic nanoparticles for specifically detecting biomarkers of Alzheimer's disease in vitro. ACS Chem Neurosci. 2011;2:500-5.

71. Fukumoto H, Tennis M, Locascio JJ, Hyman BT, Growdon JH, Irizarry MC. Age but not diagnosis is the main predictor of plasma amyloid beta-protein levels. Arch Neurol. 2003;60:958-64.

72. Fagan AM, Roe CM, Xiong C, Mintun MA, Morris JC, Holtzman DM. Cerebrospinal fluid tau/beta-amyloid(42) ratio as a prediction of cognitive decline in nondemented older adults. Arch Neurol. 2003;64:343-9.

73. Schupf N, Tang MX, Fukuyama H, Manly J, Andrews H, Mehta P, Ravetch J, Mayeux R. Peripheral $A \beta$ subspecies as risk biomarkers of Alzheimer's disease. Proc Natl Acad Sci USA. 2008;105:14052-7.

74. Ruiz A, Pesini P, Espinosa A, Pérez-Grijalba V, Valero S, Sotolongo-Grau O, Alegret M, Monleón I, Lafuente A, Buendía M, Ibarria M, Ruiz S, Hernández I, José IS, Tárraga L, Boada M, Sarasa M. Blood amyloid beta levels in healthy, mild cognitive impairment and Alzheimer's disease individuals: replication of diastolic blood pressure correlations and analysis of critical covariates. PLoS One. 2013;8:e81334-1-9.

75. Wang T, Xiao S, Liu Y, Lin Z, Su N, Li X, Li G, Zhang $M$, Fang Y. The efficacy of plasma biomarkers in early diagnosis of Alzheimer's disease. Int J Geriatr Psychiatry. 2013;29:713-9.

76. Wang T, Xiao S, Liu Y, Lin Z, Su N, Li X, Li G, Zhang $M$, Fang Y. The efficacy of plasma biomarkers in early diagnosis of Alzheimer's disease. Int J Geriatr Psychiatry. 2014;29:713-9.

77. Kaerst L, Kuhlmann A, Wedekind D, Stoeck K, Lange P, Zerr I. Cerebrospinal fluid biomarkers in Alzheimer's disease, vascular dementia and ischemic stroke patients: a critical analysis. J Neurol. 2013;260:2722-7.

78. Yang SY, Wang WC, Lan CB, Chen CH, Chieh JJ, Horng HE, Hong CY, Yang HC, Tsai CP, Yang CY, Cheng IC, Chung WC. Magnetically enhanced high-specificity virus detection using bio-activated magnetic nanoparticles with antibodies as labeling markers. J Virol Methods. 2010;164:14-8. 
79. Andreasen N, Vanmechelen E, de Voorde AV, Davidsson P, Hesse C, Tarvonen S, Räihä I, Sourander L, Winblad B, Blennow K. Cerebrospinal fluid tau protein as a biochemical marker for Alzheimer's disease: a community based follow up study. J Neurol Neurosurg Psychiatry. 1998;64:298-305.
80. Irwin DJ, Trojanowski JQ, Grossman M. Cerebrospinal fluid biomarkers for differentiation of frontotemporal lobar degeneration from Alzheimer's disease. Front Aging Neurosci. 2013;5:6-1--11. 